\title{
Effect of ligand chelation and sacrificial oxidant on the integrity of triazole-based carbene iridium water oxidation catalysts
}

\author{
Zahra Mazloomi, ${ }^{a} \S$ Jessica Margalef, ${ }^{\mathrm{a}, \S}$ Marcos Gil-Sepulcre, ${ }^{\mathrm{b}, \mathrm{c},},{ }^{*}$ Nuria Romero, ${ }^{\mathrm{b}}$ Martin \\ Albrecht, ${ }^{\mathrm{d}^{*}}$ Antoni Llobet, ${ }^{\mathrm{c}}$ Xavier Sala,${ }^{\mathrm{b}}$ Oscar Pàmies,${ }^{\mathrm{a}^{*}}$ and Montserrat Diéguez ${ }^{\mathrm{a}^{*}}$ \\ a Departament de Química Física i Inorgànica, Universitat Rovira i Virgili, C/ Marcel·lí Domingo, \\ 1, 43007 Tarragona, Spain. email: montserrat.dieguez@urv.cat \\ ${ }^{\mathrm{b}}$ Departament de Química, Universitat Autònoma de Barcelona, 08193 Cerdanyola del Vallès, \\ Barcelona, Spain \\ ${ }^{\mathrm{c}}$ Institute of Chemical Research of Catalonia (ICIQ-BIST), Avinguda Països Catalans 16, 43007 \\ Tarragona, Spain \\ ${ }^{d}$ Department of Chemistry and Biochemistry, University of Bern, Freiestrasse 3, 3012 Bern, \\ Switzerland. email: martin.albrecht@dcb.unibe.ch \\ $\S$ These authors contributed equally to this study
}

\begin{abstract}
We report the effect of replacing the pyridine group in the chelating trz Ir-water oxidation catalysts by a benzoxazole and a thiazole moiety. We have also evaluated if the presence of bidentate ligands is crucial for high activities and to avoid the decomposition into undesired heterogeneous layers. The catalytic performance of these benzoxazole/thiazole-triazolidene Ir-complexes in water oxidation was studied at variable $\mathrm{pH}$ using either $\mathrm{CAN}(\mathrm{pH}=1)$ or $\mathrm{NaIO}_{4}(\mathrm{pH}=5.6$ and 7). Electrocatalytic experiments indicated that while CAN-mediated water oxidation led to catalyst heterogeneization irrespective of the triazolylidene substituent, periodate as sacrificial oxidant preserved a homogeneously active species. Repetitive additions of sacrificial oxidant indicates higher integrity of the Ir-complex with a thiazole-substituted triazolylidene compared to ligands featuring a benzoxazole as chelating donor or no chelating group at all. Rigid chelation of the thiazole group was also established from stability measurements under highly acidic, oxidizing, and high ionic strength conditions.
\end{abstract}

\section{Introduction}

Nowadays, the major part of the energy is supplied by carbon-based sources, which are connected to severe environmental threats such as the greenhouse effect and air pollution. The strong societal demand for clean and environmentally friendly alternatives 
has spurred research into more sustainable resources and constitutes one of the most important contemporary scientific challenges. ${ }^{1}$

The sustainable production of hydrogen from water is one of the most relevant alternatives to fossil fuels. ${ }^{2}$ This process requires the coupling of two half-reactions: (i) water oxidation to produce the reducing equivalents (electrons) and oxygen as the only byproduct and (ii) reduction of protons using the electrons of the former reaction to generate molecular hydrogen. Although both reactions are crucial for the generation of hydrogen from water, the oxidation of water is the bottleneck in the water splitting process. ${ }^{3}$ The reason is that water oxidation is thermodynamically unfavorable, mechanistically complex, and slow without the use of an appropriate kinetically competent catalyst. ${ }^{3 \mathrm{c}}$ The development of powerful and stable catalysts for this process is therefore of great importance. For decades, scientists have sought to understand and imitate nature, creating both biomimetic water oxidation catalysts as well as completely artificial homogeneous ${ }^{3 \mathrm{a}-\mathrm{c}}$ and heterogeneous ${ }^{3 \mathrm{~d}}$ systems. One of the key features that water oxidation catalysts need to fulfill is a high redox flexibility of the metal center because the formation of molecular oxygen from water requires the transfer of four electrons. A variety of catalysts based on $\mathrm{Ru},{ }^{4} \mathrm{Mn},{ }^{5} \mathrm{Ir},{ }^{6} \mathrm{Co},{ }^{7}$ and $\mathrm{Fe}^{8}$ have been developed over the last decades. Generally, noble metal-based catalysts exhibit better catalytic performance than the non-noble ones.

Among the various water oxidation catalysts, homogeneous molecular systems have attracted considerable attention due to their straightforward synthesis and tunable properties by ligand design. In particular, iridium(III) complexes have recently emerged as efficient catalysts for water oxidation. ${ }^{9}$ They were first introduced in 2008 when Bernhard's group reported water oxidation with Ir complexes containing two 2phenylpyridine (ppy) ligands and two molecules of water. ${ }^{6 a}$ Crabtree and coworkers soon after demonstrated that $[\mathrm{Cp} * \operatorname{Ir}(\mathrm{ppy}) \mathrm{X}]\left(\mathrm{Cp}^{*}=1,2,3,4,5\right.$-pentamethylcyclopentadienyl $)$ complexes display improved catalytic activity. ${ }^{6 \mathrm{~b}}$ Since then, a variety of Cp*Ir-based molecular catalysts have been reported for water oxidation. ${ }^{6,9}$ While the role of the $\mathrm{Cp}^{*}$ is not fully understood, its partial or full degradation is key to access the catalytically active species. ${ }^{10}$ This catalyst activation pathway emphasizes the relevance of using robust ancillary ligands bound to the $\mathrm{IrCp}^{*}$ in order to maintain a molecular mode of action of the catalyst. It was also found that the redox behavior of the Ir center in these organometallic compounds can be modulated by the coordinated ancillary ligands. In this respect, mesoionic carbenes, such as 1,2,3-triazol-5-ylidenes (trz), have been thought to 
facilitate the stabilization of different metal oxidation states mainly because of the large contributions from zwittterionic resonance forms and also because they can serve as a transient reservoir of both negative and positive charge. ${ }^{6 \mathrm{~d}}$ Within this class of catalysts for water oxidation, Ir-complexes containing pyridyl-trz ligands have shown high efficiency. ${ }^{6 \mathrm{~d}, 11}$ For example, complex $\mathbf{I}$ accomplishes high turnover numbers (up to 38,000 after 1.5 days) in water oxidation mediated by cerium ammonium nitrate $\left(\left(\mathrm{NH}_{4}\right)_{2} \mathrm{Ce}\left(\mathrm{NO}_{3}\right)_{6}, \mathrm{CAN}, \mathrm{pH} 1\right.$; Figure 1). ${ }^{11 \mathrm{a}}$ Modification of the remote position of the trz ligand (complex II, Figure 1) led to a substantially increase in activity. ${ }^{11 b, c}$ In addition, the simple and counterintuitive introduction of the more lipophilic n-octyl chain led to one of the most active Ir-catalysts described (complex III, Figure 1). ${ }^{12}$ Nevertheless, activity substantially decreased when using sodium periodate as sacrificial oxidant in nearly neutral media ( $\mathrm{pH}$ 5.6). For instance, the turnover frequencies (TOFs) dropped from as high as $2 \mathrm{~s}^{-1}$ using $\mathrm{CAN}$ at $\mathrm{pH} 1$ to around $0.1 \mathrm{~s}^{-1}$ with $\mathrm{NaIO}_{4}$ at $\mathrm{pH} 5.6 .^{11 \mathrm{~b}}$

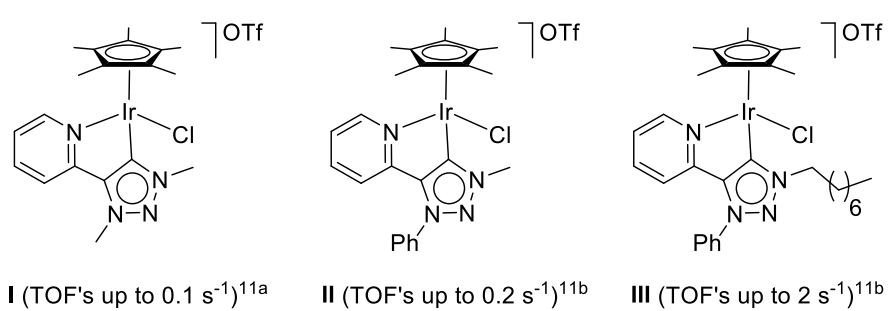

Figure 1. Representative pyridine-triazolidene iridium water oxidation catalyst precursors. TOF measured in the CAN-mediated water oxidation at $\mathrm{pH} 1$.

The development of robust water oxidation catalysts for large-scale applications, with low overpotentials, high activities and stability is still an active area of research. They must be able to maintain their activity for a long period of time under harsh reaction conditions such as a highly oxidizing environment to avoid ligand dissociation and the decomposition of the catalyst that may result in heterogeneous iridium oxides/nanoparticles or the loss of the precious metal. A key approach for further development is ligand tailoring due to the beneficial effect observed with simple and sometimes counterintuitive modifications in the trz scaffold for Ir-water oxidation catalysts. Along these lines, we recently showed that the replacement of the pyridyl group in Ir-complexes containing pyridyl-trz ligands by other robust nitrogen donor groups, such as benzoxazole and thiazole, is highly advantageous in both transfer hydrogenation and dehydrogenation reactions. ${ }^{13}$ Inspired by these achievements, we herein have studied 
the effect of replacing the pyridine group in the chelating trz iridium catalyst by a benzoxazole and a thiazole moiety for water oxidation (complexes $\mathbf{1}$ and $\mathbf{2}$; Figure 2). We have also studied the effect of the catalyst precursor charge by comparing cationic complex 1 with the neutral analogue 3. Finally, we evaluated if the presence of bidentate ligands is crucial for high activities and, more importantly, if ligand chelation is key to avoid the decomposition into undesired heterogeneous layers. For these purposes, complexes 1-3 were compared to complex 4, which does not contain a potentially chelating triazolylidene substituent. The catalytic performance of complexes 1-4 in water oxidation was studied with different sacrificial oxidants and at variable $\mathrm{pH}$ using either CAN (pH = 1) or $\mathrm{NaIO}_{4}(\mathrm{pH}=5.6$ and 7).
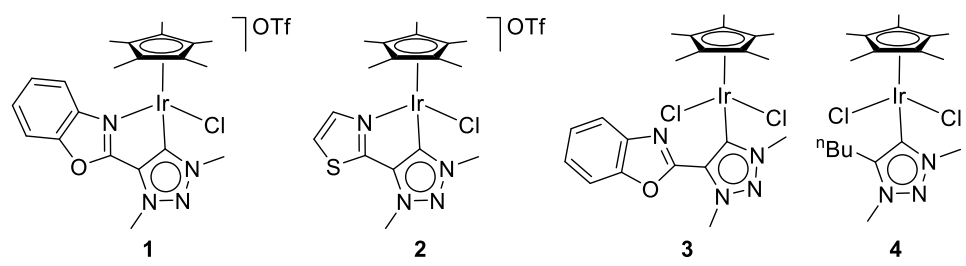

Figure 2. Ir complexes 1-4 investigated in this study for water oxidation catalysis using both $\mathrm{CAN}$ and $\mathrm{NaIO}_{4}$ as sacrificial oxidants.

\section{Results and discussion}

\subsection{Synthesis of Ir-catalyst precursors}

Complexes 1-3 were prepared as previously reported from the corresponding triazolium salt by reaction with $\mathrm{Ag}_{2} \mathrm{O}$ and $\mathrm{Me}_{4} \mathrm{NCl}$ to form the desired $\mathrm{Ag}$-carbene intermediate, and subsequent in situ transmetallation with $\left[\operatorname{Ir}\left(\mathrm{Cp}^{*}\right) \mathrm{Cl}_{2}\right]_{2} .{ }^{13}$ The new complex 4 was also synthesized using the same methodology (Scheme 1). Thus, 4-butyl1,3-dimethyl-1H-1,2,3-triazolium salt was prepared via conventional copper-catalyzed $[3+2]$ cycloaddition of methyl azide and 1-hexyne, followed by the methylation at the triazole N3 position as illustrated in Scheme 1. Complex 4 was obtained as air stable solid and was fully characterized by ${ }^{1} \mathrm{H}$ and ${ }^{13} \mathrm{C}$ NMR spectroscopy and mass spectrometry. Coordination of the 1,2,3-triazol-5-ylidene group was confirmed by the disappearance of the $\mathrm{H}-5$ proton signal in the ${ }^{1} \mathrm{H}$ NMR spectra and by the substantial downfield shift of the C-5 carbon signal in the ${ }^{13} \mathrm{C}$ NMR spectra. 


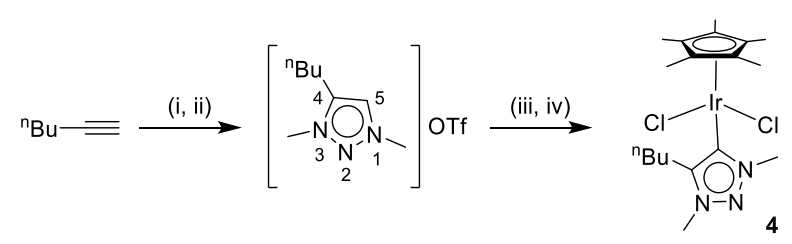

Scheme 1. Synthesis of 1,2,3-triazol-5-ylidene iridium complex 4. (i) $\mathrm{MeN}_{3}$, $\mathrm{CuSO}_{4} \cdot 5 \mathrm{H}_{2} \mathrm{O}$, sodium ascorbate, $\mathrm{THF} / \mathrm{H}_{2} \mathrm{O}$. (ii) $\mathrm{MeOTf}, \mathrm{CH}_{2} \mathrm{Cl}_{2}$. (iii) $\mathrm{Ag}_{2} \mathrm{O}, \mathrm{Me}_{4} \mathrm{NCl}$, $\left[\mathrm{IrCp} * \mathrm{Cl}_{2}\right]_{2}, \mathrm{CH}_{2} \mathrm{Cl}_{2}$.

\subsection{Reactivity towards water. Preparation of Ir-aquo complexes}

In order to investigate the $\mathrm{Cl}^{-} / \mathrm{H}_{2} \mathrm{O}$ ligand exchange propensity of complexes 1-4 in solution, their behavior in $\mathrm{D}_{2} \mathrm{O}$ was studied by in situ ${ }^{1} \mathrm{H}$ NMR spectroscopy. Interestingly, a ligand-dependent behavior was observed. Whereas complexes 1, 3 and 4 are robust and no ligand exchange was detected by ${ }^{1} \mathrm{H}$ NMR analysis even after 4 days (Scheme 2a), for complex 2 two compounds at a ratio of ca 9:1 were observed when recording the ${ }^{1} \mathrm{H}$ NMR spectrum in $\mathrm{D}_{2} \mathrm{O}$ (Scheme 2b). For instance, two sets of the thiazole signals were observed at $8.00 \mathrm{ppm}$ and $8.16 \mathrm{ppm}$ (major, complex 2) and at 8.07 ppm and $8.29 \mathrm{ppm}$ (minor). As seen in previous studies on solvation of related C,Nbidentate chelated iridium complexes, ${ }^{14}$ the downfield shift of the thiazole signals in the minor compound indicates the formation of the dicationic aquo complex $\mathbf{5}$, which is in equilibrium with the major compound 2.

(a)
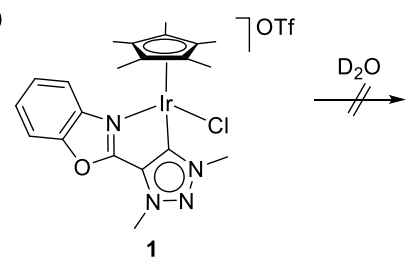

No ligand exchange
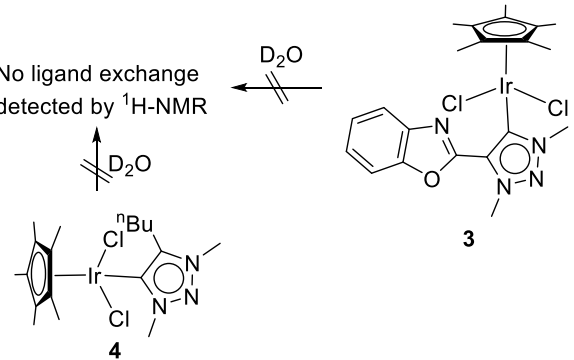

(b)
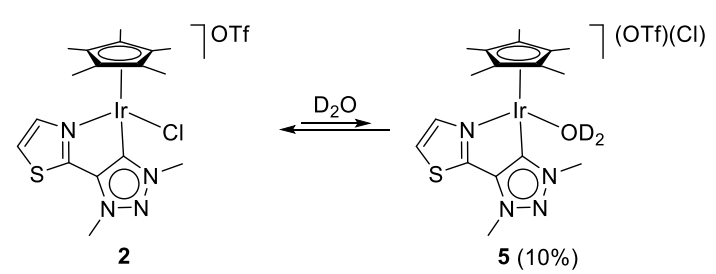

Scheme 2. $\mathrm{Cl}^{-} / \mathrm{H}_{2} \mathrm{O}$ ligand exchange equilibria of complexes 1-4.

To provide further evidence on the formation of the dicationic aquo complexes, we prepared those species by irreversible abstraction of the chloride anion with silver triflate 
in water (Scheme 3). In line with the different behavior of complexes $\mathbf{1}$ and $\mathbf{2}$ in aqueous solution previously observed, the formation of the benzoxazole-based dicationic aquo complex 6 required longer reaction times (2 days) than the thiazole analogue $5(12 \mathrm{~h})$. Complexes 5 and 6 were characterized by ${ }^{1} \mathrm{H}$ and ${ }^{13} \mathrm{C}$ NMR spectroscopy and mass spectrometry. The HRMS-ESI spectra showed the heaviest ions at $\mathrm{m} / \mathrm{z}$ that correspond to the loss of the solvato ligand and the triflate anion. For both complexes the benzoxazole and thiazole signals appeared more downfield shifted than those of the cationic chloro complexes $\mathbf{1}$ and 2. In addition, the ${ }^{13} \mathrm{C}$ NMR spectra of complexes $\mathbf{5}$ and $\mathbf{6}$ showed the signals of the quaternary $\mathrm{X}-\mathrm{C}=\mathrm{N}(\mathrm{X}=\mathrm{O}, \mathrm{S})$ group further downfield shifted than those of the free ligand (i.e. $153.8 \mathrm{ppm}$ for complex $\mathbf{6}$ and $151.2 \mathrm{ppm}$ for the benzoxazoletriazolium salt). This chemical shift agrees with coordination of the benzoxazole and thiazole moieties to the Ir-center, and therefore indicates that only one water molecule is coordinated in complexes $\mathbf{5}$ and $\mathbf{6}$. The molecular structure of $\mathbf{5}$ was further confirmed by X-ray diffraction analysis (Scheme 3). Although the structure showed high disorder at the $\mathrm{Cp}^{*}$, it confirmed a piano-stool arrangement with bidentate thiazole-triazolylidene ligand coordination and the presence of a single water molecule bound to iridium.

When the monoaquo complex 6 is kept in water at $70{ }^{\circ} \mathrm{C}$ for more than 3 days, coordination of a second molecule of water was observed, producing complex 7 (Scheme 3). Coordination of the second water molecule involves dissociation of the benzoxazole unit, which was indicated by a more pronounced shielding of the benzoxaole protons in the ${ }^{1} \mathrm{H}$ NMR spectrum (Figure S17). No such decoordination was observed with complex 5 even upon heating for 1 week, suggesting that the thiazole unit is stronger bound than the benzoxazole moiety. Treatment of $\mathbf{4}$ with two equivalents of AgOTf in water led to the clean formation of the diaquo complex 8 . 


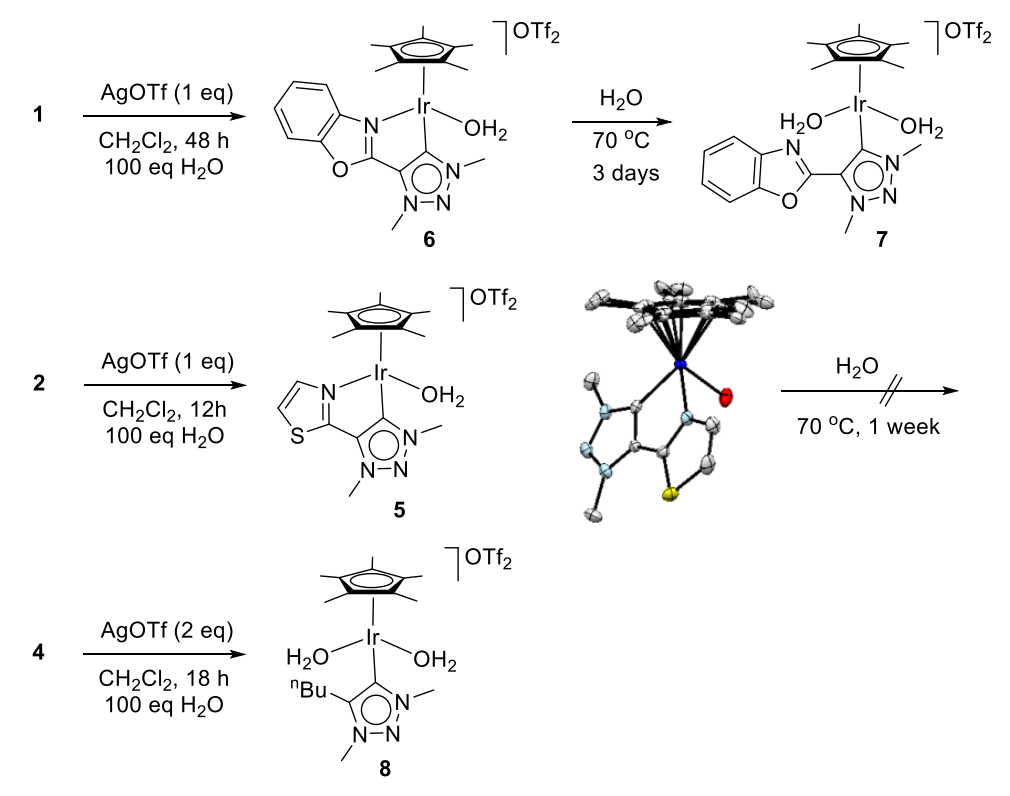

Scheme 3. Preparation of dicationic aquo complexes 5-8

\subsection{Stability studies in acid media and in the presence of $\mathrm{NaI}$ and $\mathrm{NaIO}_{3}$}

The behavior of these iridum complexes under acidic conditions $(\mathrm{pH} 1)$ as required for the CAN-promoted water oxidation reaction was investigated by exposing complexes 1-8 to DCl and DOTf, respectively (0.1 M; Scheme 4). The mere addition of DCl to the $\mathrm{D}_{2} \mathrm{O}$ solutions of the complexes shifts the ${ }^{1} \mathrm{H}$ NMR signals to higher field because of the higher ion concentration. For example, for complex 1 the $\mathrm{N}_{\mathrm{trz}}-\mathrm{CH}_{3}$ resonances shift from 4.62 and $4.43 \mathrm{ppm}$ in $\mathrm{D}_{2} \mathrm{O}$ to 4.07 and $3.84 \mathrm{ppm}$ in DCl. Moreover, the addition of $\mathrm{DCl}$ to a $\mathrm{D}_{2} \mathrm{O}$ solution of $\mathbf{1}$ induced partial benzoxazole decoordination as identified by minor signals of complex 3 (Figure S18). On the other hand, the addition of $\mathrm{DCl}$ to the corresponding aquo derivatives $\mathbf{6}$ and $\mathbf{7}$ led to fast formation of the chloro-derivatives $\mathbf{1}$ and 3, respectively (Figure S19) and some unidentified resonances after less than $1 \mathrm{~h}$, suggesting a limited stability of the complexes under these conditions. Complex $\mathbf{4}$ and its aquo-derivative $\mathbf{8}$ also showed low stability in $\mathrm{DCl}$, indicated by the formation of unidentified signals after $30 \mathrm{~min}$. Decomposition was faster for complexes $\mathbf{3}, \mathbf{4}, \mathbf{7}$, and 8 with a monodentate trz ligand and slower for the chelating benzoxazole-trz complexes 1 and 6. The complexes were even less stable in DOTf $(0.1 \mathrm{M})$ as suggested by the immediate appearance of decomposition products according to ${ }^{1} \mathrm{H}$ NMR spectroscopy, even for the more stable complex 1 (Figure S20). 
(a)

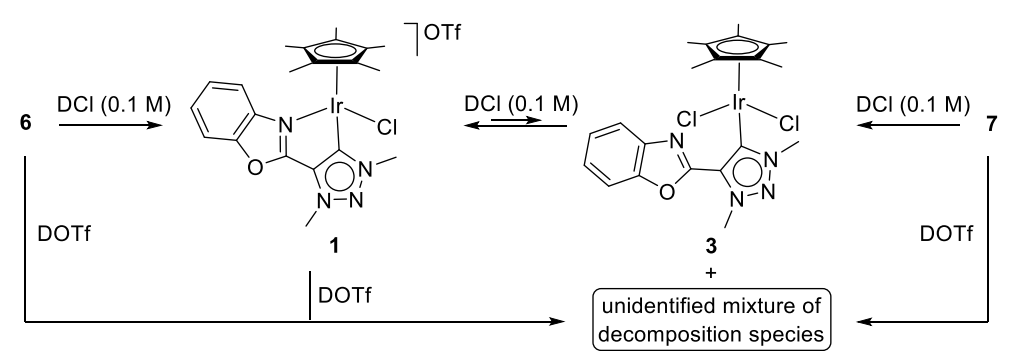

(b)

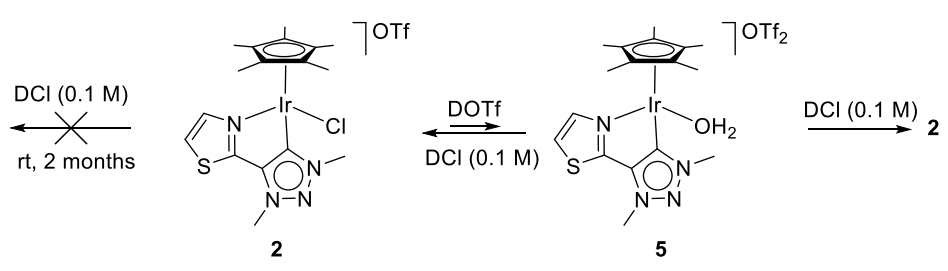

Scheme 4. Stability properties of complexes 1-3 and 5-7 under acidic conditions.

In contrast, the thiazole-based complex 2 was stable in $\mathrm{DCl}$ and no further reactions nor decomposition were observed even after two months (Figure S21). As expected, the aquo-complex 5 reacts with DCl to form complex 2 . The addition of DOTf to an aqueous solution of $\mathbf{2}$ showed an equilibrium with the dicationic monoaquo complex $\mathbf{5}$, which is stable for at least one month (Figure S22).

In summary, these investigations demonstrate that the stability of the complexes in acidic media directly depends on the nature of the chelating group. Thus, the thiazole-trz ligand is rigidly bidentate coordinating to $\mathrm{Ir}$ and induces reversible solvolysis of the ancillary ligand. In contrast, the benzoxazole-unit is labile and dissociates under acidic conditions, leading to unstable complexes that decompose within hours.

In order to mimic the conditions required in $\mathrm{NaIO}_{4}$-promoted water oxidation, we studied the stability of complexes 1 and $\mathbf{2}$ in presence of $\mathrm{NaI}$ or $\mathrm{NaIO}_{3}$. Addition of $\mathrm{NaI}$ ( 1 eq) to solutions of $\mathbf{1}$ and $\mathbf{2}$ led to the expected exchange of chloride by iodide to form complexes 9 and 10 (Scheme 5). Again, the thiazole-trz iridium complex 10 is stable over time, while the benzoxazole-based analogue 9 reacts further and forms an equilibrium with the neutral diiodie complex 11 within $48 \mathrm{~h}$. This equilibrium demonstrates the relatively weak bonding of benzoxazole to the iridium(III) center, and it was shifted further towards complex 11 upon addition of excess NaI. Under these conditions, the thiazole-trz complex forms complex 12 as confirmed by elemental analysis and the lack of fluorine signals in the ${ }^{19} \mathrm{~F}$ NMR spectra, again suggesting a robust chelation of the thiazole unit. No reactions were observed for complexes 1 and $\mathbf{2}$ with $\mathrm{NaIO}_{3}$ (Scheme 5). 


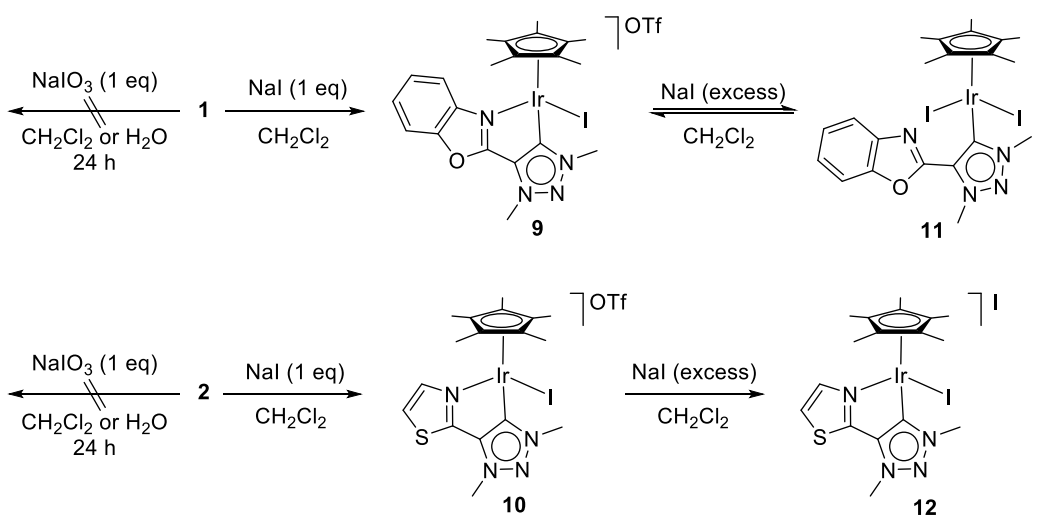

Scheme 5. Reactivity of complexes $\mathbf{1}$ and 2 with $\mathrm{NaI}$ and $\mathrm{NaIO}_{3}$.

\subsection{Water oxidation experiments}

The catalytic performance of complexes 1-4 towards water oxidation was studied at different $\mathrm{pH}$ conditions using $\left(\mathrm{NH}_{4}\right)_{2} \mathrm{Ce}\left(\mathrm{NO}_{3}\right)_{6}(\mathrm{CAN})$ or sodium periodate as sacrificial oxidants. ${ }^{15}$ The amount of $\mathrm{O}_{2}$ and other possible gases released during the catalytic process was monitored by combining manometric techniques and $\mathrm{O}_{2}$-selective Clark-electrode in a home-made thermostated glass reactor at $25{ }^{\circ} \mathrm{C}$.

\subsubsection{Water oxidation catalysis at pH 1 using CAN as sacrificial oxidant}

The first set of water oxidation experiments was carried out in a 0.1 M HOTf solution (pH 1) by mixing complexes 1-4 (1 mM) and CAN (100 mM). ${ }^{16}$ TON values $\left(\mathrm{TON}_{\max }=25\right)$ were calculated at the end of each catalytic experiment. Moreover, three consecutive injections were performed in order to investigate the productivity of the different CAN equivalents. 
A

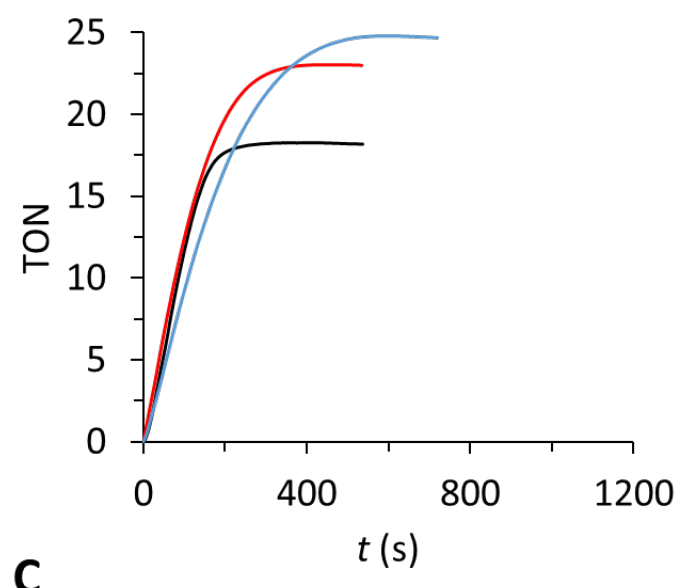

C

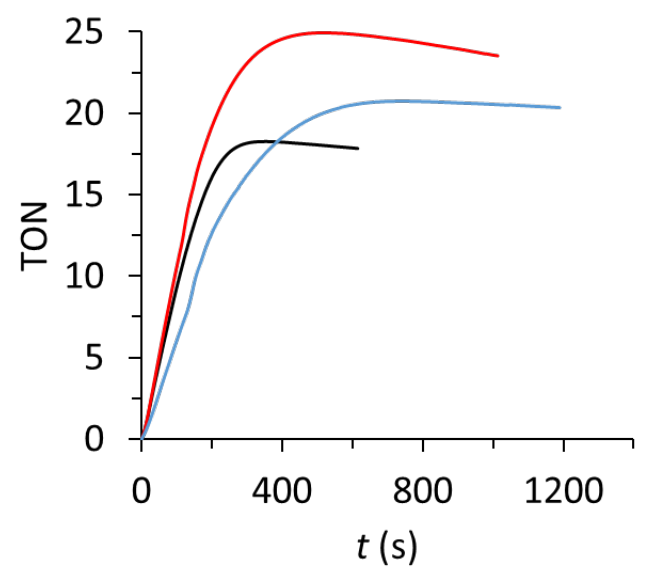

B

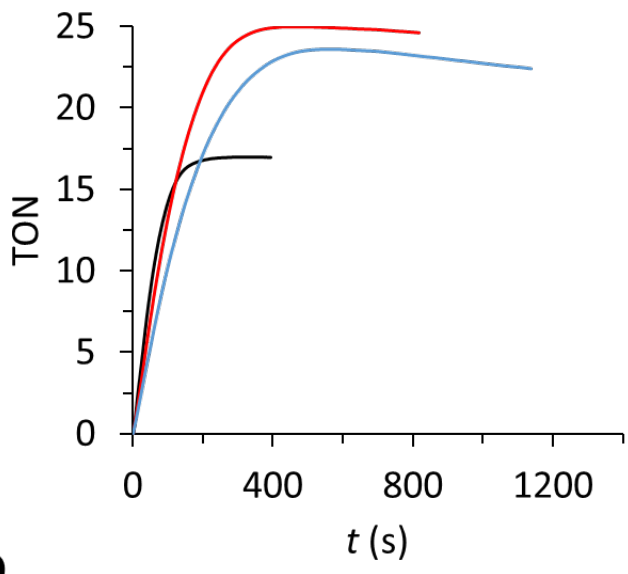

D

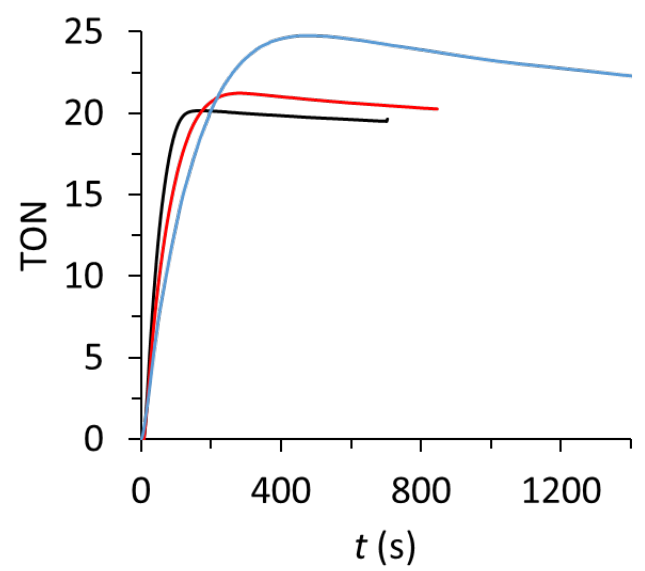

Figure 3. Manometric monitoring of gas evolution vs. time for complexes 1 (A), 2 (B), 3 (C) and 4 (D) during three consecutive additions of 100 eq. CAN (black line: $1^{\text {st }}$ injection, red line: $2^{\text {nd }}$ injection, blue line: $3^{\text {rd }}$ injection). Reaction conditions: $1 \mathrm{mM}$ complex in 0.1 $\mathrm{M}$ triflic acid solution, $100 \mathrm{mM}$ CAN.

In all cases, manometric measurements showed a fast production of gas after the addition of CAN (Figure 3; Figure S24), together with a loss of the characteristic orange color of CAN and formation of the expected blue-purple solutions indicative of the consumption of the sacrificial oxidant. ${ }^{17,10 \mathrm{~d}}$ With complexes $\mathbf{1}-\mathbf{3}$, the first CAN injection gave only 17-18 turnovers instead of the theoretical 25 ( $75 \%$ of efficiency with respect to $\mathrm{CAN}$ ), while the subsequent injections produce almost quantitative amounts of $\mathrm{O}_{2}$ (Table $\mathrm{S} 1$ ). The incomplete $\mathrm{O}_{2}$ evolution in the first injection suggests the non-productive use of 25 equiv CAN for catalyst activation. This activation process is in line with previous work on pyridyl-trz $\operatorname{Ir}\left(\mathrm{Cp}^{*}\right)$ complexes, which required 30 equiv CAN for catalyst activation prior to $\mathrm{O}_{2}$ evolution. ${ }^{11 a} \mathrm{O}$ note, 25 equiv $\mathrm{CAN}$ are insufficient for full 
$\mathrm{Cp}$ * degradation to $\mathrm{CO}_{2}$ and therefore suggest only partial oxidation. ${ }^{11 \mathrm{~b}}$ Moreover, ${ }^{1} \mathrm{H}$ NMR spectra under catalytic conditions showed the gradual disappearance of the $\mathrm{Cp}^{*}$ signal and concomitant formation of acetic acid, which supports partial oxidation of $\mathrm{Cp}{ }^{*} .{ }^{9 b}$ Other processes like oxidation of residual organic solvent or the halide ligand, or oxidation the glass walls of the reaction vessel were ruled for the deliberate consumption of the initial 25 CAN equivalents. ${ }^{18}$ The TOF values under these high catalyst concentrations are highest for complex $4\left(\mathrm{TOF}=0.24 \mathrm{~s}^{-1}\right)$, followed by $2\left(\mathrm{TOF}=0.12 \mathrm{~s}^{-}\right.$ ${ }^{1}$ ), and lowest for the benzoxazole-trz complexes 1 and 3 (TOFs $=0.07 \mathrm{~s}^{-1}$ and $0.06 \mathrm{~s}^{-1}$, respectively, Table $\mathrm{S} 2$ ). Generally, these TOF values are among the common reported in the literature for related Ir-based water oxidation catalysts when using CAN as sacrificial oxidant (see Table S2).

To elucidate the nature of the active species formed during the catalytic experiments, the resulting solutions were analysed by dynamic light scattering (DLS). All solutions showed particles of similar size to those found in a blank solution of CAN in $0.1 \mathrm{M}$ HOTf $(0.7 \mathrm{~nm}$ diameter, Table S3). This suggests that these particles potentially arose from impurities in the sacrificial oxidant or from small clusters formed by its degradation, ${ }^{19}$ even though, the presence of small $\mathrm{IrO}_{\mathrm{x}}$ nanoparticles cannot be completely ruled out. ${ }^{61}$ In order to further evaluate whether heterogeneous material is formed during catalysis, we investigated the long term stability of complexes 1-4 in aqueous solutions at $\mathrm{pH} 1$ electrochemically. Initially, $\mathrm{CV}$ experiments of $\mathbf{1}-\mathbf{4}$ in $0.1 \mathrm{M}$ HOTf showed one irreversible wave in the 1.31-1.53 V range, which was assigned to the $\operatorname{Ir}(\mathrm{IV}) / \mathrm{Ir}(\mathrm{III})$ redox couple (Figure S26). The irreversible character of the $\operatorname{Ir}(\mathrm{IV}) / \mathrm{Ir}(\mathrm{III})$ oxidation suggests that iridium oxidation triggers chemical modification of the complex, which aligns with the unproductive consumption of the first few CAN equivalents under catalytic conditions (see Figure 3 above). At higher potentials, a catalytic current appeared which was attributed to electrocatalytic water oxidation. After 10 consecutive $\mathrm{CV}$ cycles between 0.2 and $2.0 \mathrm{~V}$ vs NHE (Figure S27), a significant increase in the maximum current $\left(I_{\max }\right)$ of the electrocatalytic wave for complexes 1, 3 and $\mathbf{4}$ was observed, whereas high and stable currents were found for the thiazole-trz complex 2. The different behavior of $\mathbf{2}$ agrees well with its higher stability under acidic conditions compared to complexes 1, 3 and $\mathbf{4}$ ( $c f$ previous section). For all complexes, a decrease in the current of the $\operatorname{Ir}(\mathrm{IV}) / \mathrm{Ir}(\mathrm{III})$ wave was also observed, which supports the irreversible oxidation of catalyst precursor. After successive cycling, the employed electrodes were washed with water, acetone and methanol and immersed in a fresh 0.1 M HOTf solution. 
The CVs recorded with these rinsed electrodes showed a significant catalytic current, indicating the presence of active heterogeneous material deposited onto the glassy carbon electrode (Figure S28). ${ }^{20}$ This behavior is independent of the iridium precursor used (complexes 1-4). Complex degradation is also in agreement with the low stability of the complexes under acidic conditions even before applying oxidative stress.

\subsubsection{Water oxidation catalysis at pH 5.6 and 7 using $\mathrm{NaIO}_{4}$ as sacrificial oxidant}

Since the stability of the complexes under neutral conditions is much higher, we investigated the catalytic water oxidation activity of complexes 1-4 at $\mathrm{pH} 5.6$ using sodium periodate $\left(\mathrm{NaIO}_{4}\right)$ as sacrificial oxidant. ${ }^{21}$ An experiment at high catalyst loading (1:50 ratio of complex 2 vs $\mathrm{NaIO}_{4}$ ) gave $\sim 21$ turnovers, indicating that 16 oxidation equivalents were used unproductively (Figure S29). These equivalents are very similar to those observed in CAN-mediated water oxidation and suggest a related oxidative catalyst activation mechanism with both sacrificial oxidants. When decreasing the catalyst/NaIO 4 ratio, these unproductive equivalents become negligible. For example, the use of standard conditions as developed by Crabtree and Brudvig, ${ }^{21}$ i.e. $5 \mu \mathrm{M}$ of iridium and $20 \mathrm{mM}$ $\mathrm{NaIO}_{4}$ (4000 eq) in $0.1 \mathrm{M} \mathrm{NaOAc}$ led to complete consumption of $\mathrm{NaIO}_{4}$ for all complexes 1-4 and efficiencies of essentially 100\% (Table 1; entries 1-4; Figure S30). The TOFs were higher than those obtained with CAN as sacrificial oxidant and reached $0.5 \mathrm{~s}^{-1}$ with the monodentate trz complexes 3 and 4 (0.49 and $0.51 \mathrm{~s}^{-1}$, respectively). Complexes $\mathbf{1}$ and $\mathbf{2}$ containing a chelating benzoxazole and thiazole-trz ligand, respectively, had slightly lower TOFs of ca $0.3 \mathrm{~s}^{-1}$. 
Table 1. Catalytic results for the $\mathrm{NaIO}_{4}$-promoted water oxidation catalyzed by complexes 1-4.

\begin{tabular}{ccccccc}
\hline Entry & Cat. precursor & {$[\mathrm{Cat}]$} & {$\left[\mathrm{NaIO}_{4}\right]$} & $\mathrm{pH}$ & $\mathrm{TOF}\left(\mathrm{s}^{-1}\right)^{\mathrm{a}}$ & $\mathrm{TON}$ \\
\hline 1 & $\mathbf{1}$ & & & & 0.33 & $2,000^{\mathrm{b}}$ \\
2 & $\mathbf{2}$ & $5 \mu \mathrm{M}$ & $20 \mathrm{mM}$ & 5.6 & 0.27 & $2,000^{\mathrm{b}}$ \\
3 & $\mathbf{3}$ & & & & 0.49 & $2,000^{\mathrm{b}}$ \\
4 & $\mathbf{4}$ & & & & 0.51 & $2,000^{\mathrm{b}}$ \\
\hline 5 & $\mathbf{1}$ & & & & 0.29 & $5,300^{\mathrm{c}}$ \\
6 & $\mathbf{2}$ & \multirow{2}{*}{$\mathrm{NM}$} & $4 \times 20 \mathrm{mM}$ & 5.6 & 0.68 & $20,000^{\mathrm{c}}$ \\
7 & $\mathbf{3}$ & & & & 0.77 & $19,000^{\mathrm{c}}$ \\
8 & $\mathbf{4}$ & & & & 4.24 & $20,000^{\mathrm{c}}$ \\
\hline 9 & $\mathbf{1}$ & & & & 1.02 & $20,000^{\mathrm{c}}$ \\
10 & $\mathbf{2}$ & & & & 2.22 & $20,000^{\mathrm{c}}$ \\
11 & $\mathbf{3}$ & $2 \mu \mathrm{M}$ & $4 \times 20 \mathrm{mM}$ & 7 & 2.09 & $20,000^{\mathrm{c}}$ \\
12 & $\mathbf{4}$ & & & & 1.78 & $20,000^{\mathrm{c}}$
\end{tabular}

${ }^{a}$ TOF values were determined from at least duplicate runs and were extracted from a linear region during the first 30 minutes of catalysis with errors between measurements consistently $<10 \%$. ${ }^{b}$ From $\mathrm{O}_{2}$-selective Clark-type electrode analysis of the reaction headspace $\left(\mathrm{TON}_{\max }=2,000\right){ }^{\mathrm{c}}$ TON measured after four consecutive runs $\left(\mathrm{TON}_{\max }=20,000\right)$.

The potential formation of heterogeneous active material under catalytic turnover conditions was again examined by a combination of DLS and electrochemical measurements. $\mathrm{CV}$ experiments performed at $\mathrm{pH} 5.6$ with complexes 1-4 show a catalytic current starting immediately after reaching the $\operatorname{Ir}(\mathrm{IV})$ oxidation state at about $1.3 \mathrm{~V}$ (Figure S31 and Figure S23). In contrast to the results obtained with $\mathrm{CAN}$ at $\mathrm{pH} 1$, however, the electrodes did not show any catalytic activity after repetitive cycling and subsequent immersion into a fresh $\mathrm{NaOAc}$ solution, indicating no deposition of catalytically active material onto the electrodes (Figures S32 and S33). Moreover, DLS experiments indicate the absence of any nanoparticles after water oxidation catalysis. Hence, these data strongly support a homogeneous nature of the catalytically active species when $\mathrm{NaIO}_{4}$ is employed as sacrificial oxidant at $\mathrm{pH} 5.6 .^{22,23}$

We therefore investigated the long-term activity of the complexes by monitoring the $\mathrm{O}_{2}$ evolution during four consecutive injections of 10,000 eq. $\mathrm{NaIO}_{4}$ each $(40,000$ eq. per Ir in total, Figure S34 and Table 1; entries 5-8). As for complex 1, the maximum efficiency with respect to the sacrificial oxidant was achieved during the first $\mathrm{NaIO}_{4}$ 
injection ( $\mathrm{TOF}=0.29 \mathrm{~s}^{-1}$, entry 5). A clear reduction in the activity was observed during the second run, indicating severe catalyst deactivation (5300 TON). On the contrary, complexes 2-4 showed a higher stability along the four consecutive $\mathrm{NaIO}_{4}$ injections (Figure S32). Thus, complex 2 bearing the thiazole-triazolylidene ligand showed excellent performance and achieved an overall TON of 20,000, and a competitive TOF value of $0.68 \mathrm{~s}^{-1}$ (entry 6). Similar TON and TOF values were recorded for complex 3 with 20,000 TON and TOF $=0.77 \mathrm{~s}^{-1}$ (entry 7). The different performance of complexes 1 and $\mathbf{3}$ under the same catalytic conditions suggests that the monodentate coordination of the benzoxaxole ligand in $\mathbf{3}$ is maintained under turnover conditions, thus retaining both chlorido ligands in the Ir coordination sphere. Whereas precatalysts 1, 2 and $\mathbf{3}$ yielded similar TOF values when $\mathrm{NaIO}_{4}$ was increased from 4,000 eq. to 10000 eq., the rate surprisingly increased by one order of magnitude for complex 4 (Table 1; entry 8 vs 4) and reached a value higher than $4 \mathrm{~s}^{-1}$. Even though this value identifies complex 4 as one of the fastest Ir-based water oxidation catalysts reported under these conditions in the literature (Table S4), ${ }^{6 k, 12 b, 21}$ the origin of the increase is unclear and unexpected for presumed first-order kinetics, which may hint to a more complex active species such as a oligo-iridium cluster that is not formed under less dilute conditions. ${ }^{24}$

The performance of complexes 1-3 considerably improved when the high turnover experiments were performed at $\mathrm{pH} 7 \mathrm{using}$ a $0.1 \mathrm{M}$ phosphate buffer solution. ${ }^{6 \mathrm{k}}$ As shown in Figure 4, at neutral $\mathrm{pH}$ periodate was consumed completely after $2 \mathrm{~h}$ of the first injection. While the theoretical turnover was achieved with all complexes and even complex 1 accomplished 20,000 turnovers, the repetitive injections also showed an enhanced stability and less pronounced deactivation at $\mathrm{pH} 7$ when comparing consecutive runs (Figure 4). Especially for complex 2 retains most of its catalytic performance upon multiple $\mathrm{NaIO}_{4}$ injections (69\% retention after four consecutive runs), while the benzoxazole analogue lost almost all activity (15\% retention; Table S5 and Figure S39). The enhanced integrity of the catalytically active species derived from complex 2 ties in very well with the higher stability and robust ligand chelation of the thiazole-trz ligand in complex 2 under acidic conditions and in the presence of NaI. In addition, the TOF generally increased when performing the water oxidation at higher $\mathrm{pH}$, e.g. complex 2 reached $2.2 \mathrm{~s}^{-1}$ ( $c f 0.68 \mathrm{~s}^{-1}$ at $\mathrm{pH} 5.6$; Table 1 entry 6 vs 10), identifying complex 2 as highly competitive compared to other known Ir-based pre-catalysts (Table S4). Similar three-fold rate-enhancing effects were observed for complexes $\mathbf{1}$ and $\mathbf{3}$, which can be 
rationalized by the $\mathrm{pH}$ dependence of the water oxidation potential and hence a larger overpotential at higher $\mathrm{pH}^{25}$

A

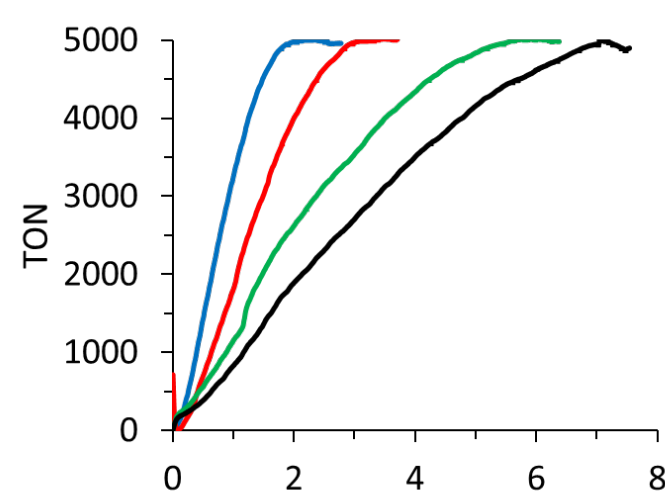

C

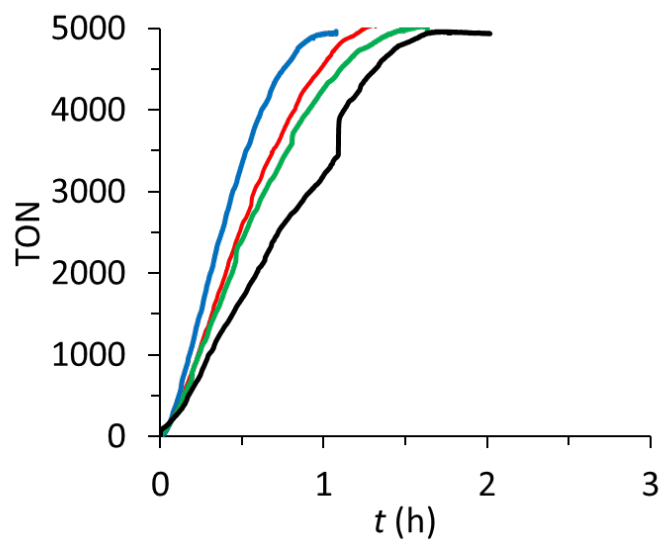

B
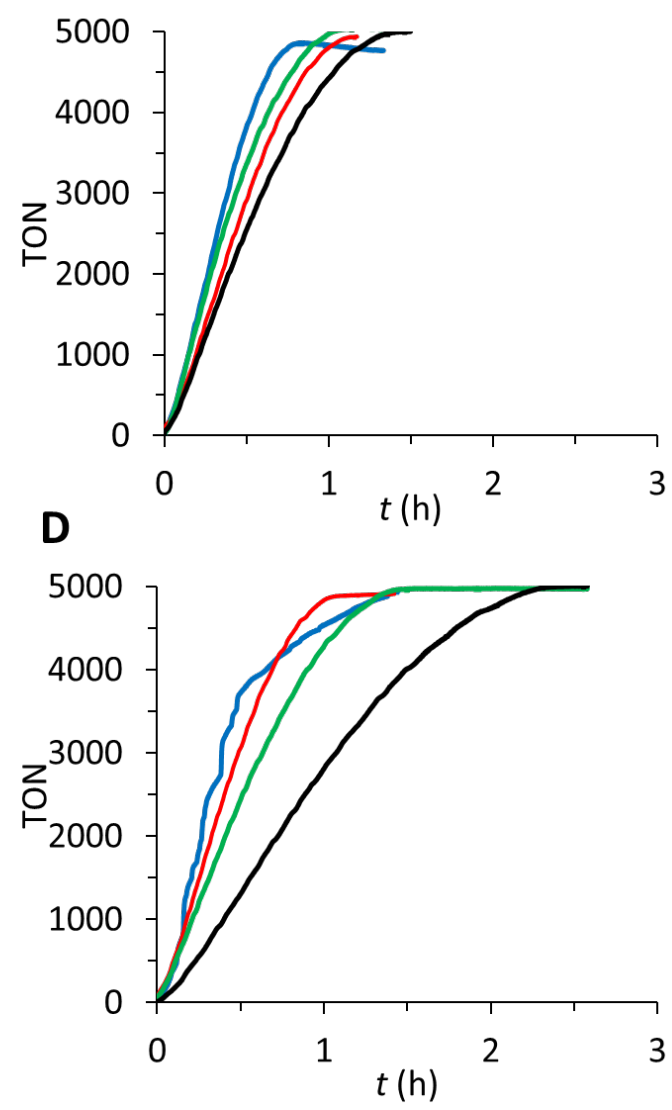

Figure 4. Plot of $\mathrm{O}_{2}$ evolution vs time of complexes 1 (A), 2 (B); 3 (C) and 4 (D) during four consecutive runs. Color code: first run (blue line), second run (red line), third run (green line) and fourth run (black line). Reaction conditions: $2 \mu \mathrm{M}$ catalyst, $0.1 \mathrm{M}$ phosphate buffer $(\mathrm{pH}=7), 20 \mathrm{mM} \mathrm{NaIO}_{4} . \mathrm{O}_{2}$ evolution measured using a selective Clarkelectrode analysis of the reaction headspace.

\section{Conclusions}

Here we have investigated iridium complexes with differently stabilized triazolederived carbene ligands for water oxidation catalysis. While $\mathrm{Ce}(\mathrm{IV})$-mediated water oxidation led to catalyst heterogeneization irrespective of the triazolylidene substituent, periodate as sacrificial oxidant preserved a homogeneously active species. Repetitive additions of sacrificial oxidant indicate a considerably higher integrity of the iridium complex containing a thiazole-substituted triazolylidene compared to ligands featuring a benzoxazole as chelating donor or no chelating group at all. Rigid chelation of the thiazole 
group was also established from stability measurements under strongly acidic, oxidizing, and high ionic strength conditions. These results emphasize the key role of appropriate chelation for designing robust and active water oxidation catalysts for high turnover applications. Moreover, mechanistic analysis indicate that irrespective of the sacrificial oxidant, about 20 oxidizing equivalents are initially used unproductively for catalyst activation, which supports a partial and presumably programmed $\mathrm{Cp} *$ degradation as the major pathway to generate the catalytically competent species.

\section{Experimental section}

\subsection{General information}

All reactions for the synthesis of Ir-complexes were carried out using standard Schlenk techniques under an atmosphere of argon. Solvents were purified and dried by standard procedures. Ir-complexes 1-3 were prepared as previously described. ${ }^{13}$ All other commercially available reagents and substrates were used as received. ${ }^{1} \mathrm{H},{ }^{13} \mathrm{C}\left\{{ }^{1} \mathrm{H}\right\}$, and ${ }^{19} \mathrm{~F}\left\{{ }^{1} \mathrm{H}\right\}$ NMR spectra were recorded using a $400 \mathrm{MHz}$ spectrometer. Chemical shifts are relative to that of $\mathrm{SiMe}_{4}\left({ }^{1} \mathrm{H}\right.$ and $\left.{ }^{13} \mathrm{C}\right)$ as internal standard. ${ }^{1} \mathrm{H}$ and ${ }^{13} \mathrm{C}$ assignments were made on the basis of ${ }^{1} \mathrm{H}-{ }^{1} \mathrm{H}$ gCOSY, ${ }^{1} \mathrm{H}-{ }^{13} \mathrm{C}$ gHSQC and ${ }^{1} \mathrm{H}-{ }^{13} \mathrm{C}$ gHMBC experiments. Dynamic light scattering experiments (DLS) were carried out using a Zetazizer Nano ZS at $25{ }^{\circ} \mathrm{C}$ with an operating range of measurement from $0.3 \mathrm{~nm}$ to 10 microns.

\subsection{Preparation of 4-butyl-1,3-dimethyl-1H-1,2,3-triazole \\ trifluoromethanesulfonate}

A suspension of $\mathrm{MeI}(0.58 \mathrm{ml}, 9.33 \mathrm{mmol})$ and $\mathrm{NaN}_{3}(1.84 \mathrm{~g}, 28 \mathrm{mmol})$ in $\mathrm{H}_{2} \mathrm{O} / \mathrm{THF}$

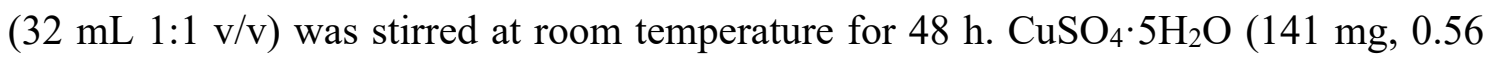
$\mathrm{mmol})$, sodium ascorbate $(1.12 \mathrm{~g}, 5.65 \mathrm{mmol})$ and 1-hexyne $(1.33 \mathrm{~g}, 11.2 \mathrm{mmol})$ were added subsequently and the mixture was stirred in the oil bath at $55^{\circ} \mathrm{C}$ for 48 hours. The organic solvent (THF) was removed under reduced pressure and the residue was suspended in $\mathrm{CH}_{2} \mathrm{Cl}_{2}(40 \mathrm{~mL})$ and washed with water $(2 \times 50 \mathrm{~mL})$, and brine $(2 \times 50 \mathrm{~mL})$. After drying over $\mathrm{MgSO}_{4}$, charcoal was added to the solution and stirred for $30 \mathrm{~min}$ to further purify the compound. The suspension filtered off through celite, washed with $\mathrm{CH}_{2} \mathrm{Cl}_{2}(30 \mathrm{ml})$ and evaporated the solvent to obtain 4-butyl-1-methyl-1H-1,2,3-triazole as a white powder. The compound is suitable to be used for the next step. Yield: $750 \mathrm{mg}$ (48\%) ${ }^{1} \mathrm{H}$ NMR (400 MHz, $\left.\mathrm{CDCl}_{3}\right): \delta=7.24$ (s, 1H, H-5), $4.01\left(\mathrm{~s}, 3 \mathrm{H}, \mathrm{CH}_{3}-\mathrm{N}\right), 2.69-$ $2.63\left(\mathrm{t},{ }^{3} \mathrm{~J}_{\mathrm{H}-\mathrm{H}}=7.3 \mathrm{~Hz}, 2 \mathrm{H}, \mathrm{CH}_{2}-\mathrm{C}_{4}\right.$ ), 1.60 (quintet, $2 \mathrm{H}, \mathrm{CH}_{2}-\mathrm{CH}_{2}$ ), 1.33 (sextet, $2 \mathrm{H}$, 
$\left.\mathrm{CH}_{2}-\mathrm{CH}_{3}\right), 0.88\left(\mathrm{t},{ }^{3} J_{\mathrm{H}-\mathrm{H}}=7.3 \mathrm{~Hz}, 3 \mathrm{H}, \mathrm{CH}_{3}, \mathrm{n}-\mathrm{Bu}\right) .{ }^{13} \mathrm{C}\left\{{ }^{1} \mathrm{H}\right\}$ NMR $\left(100 \mathrm{MHz}, \mathrm{CDCl}_{3}\right): \delta$ $=148.8(\mathrm{C}-4), 121.7(\mathrm{C}-5), 36.5\left(\mathrm{CH}_{3}-\mathrm{N}\right), 31.6\left(\mathrm{CH}_{2}-\mathrm{CH}_{2}\right), 25.3\left(\mathrm{CH}_{2}-\mathrm{CH}_{2}\right), 22.3$ $\left(\mathrm{CH}_{2}-\mathrm{CH}_{3}\right), 13.8\left(\mathrm{CH}_{3}, \mathrm{n}-\mathrm{Bu}\right)$. MS HR-ESI [found $139.1116(\mathrm{M}-\mathrm{H})^{+}, \mathrm{C}_{7} \mathrm{H}_{13} \mathrm{~N}_{3}$ requires 139.1109].

MeOTf (600 $\mu \mathrm{L}, 6.20 \mathrm{mmol}, 1.2$ equiv) was added to a solution of 4-butyl-1-methyl$1 \mathrm{H}$-1,2,3-triazole $(713 \mathrm{mg}, 5.13 \mathrm{mmol})$ in $\mathrm{CH}_{2} \mathrm{Cl}_{2}(5 \mathrm{~mL})$ at $0{ }^{\circ} \mathrm{C}$ then the solution kept to stir at $23{ }^{\circ} \mathrm{C}$ for $12 \mathrm{~h}$ (the reaction monitored by TLC). All volatiles were evaporated under reduced pressure. Purification by column chromatography $\left(\mathrm{SiO}_{2} ; \mathrm{CH}_{2} \mathrm{Cl}_{2} / \mathrm{MeOH}\right.$ $30: 1)$ yielded the desired salt as a pale yellow liquid.Yield: $1.00 \mathrm{~g}(64 \%) .{ }^{1} \mathrm{H}$ NMR (400 $\left.\mathrm{MHz}, \mathrm{CDCl}_{3}\right): \delta 8.43\left(\mathrm{~s}, 1 \mathrm{H}, \mathrm{H}_{5}\right), 4.27\left(\mathrm{~s}, 3 \mathrm{H}, \mathrm{CH}_{3}-\mathrm{N}\right), 4.16\left(\mathrm{~s}, 3 \mathrm{H}, \mathrm{CH}_{3}-\mathrm{N}\right), 2.78(\mathrm{t}, 2 \mathrm{H}$, ${ }^{3} J_{\mathrm{H}-\mathrm{H}}=15.96, \mathrm{CH}_{2} \mathrm{CH}_{2}$ ), 1.69 (quintet, $2 \mathrm{H}, \mathrm{CH}_{2} \mathrm{CH}_{2}$ ), 1.42 (sextet, $2 \mathrm{H}, \mathrm{CH}_{2} \mathrm{CH}_{3}$ ), 0.93 (t, $\left.{ }^{3} J_{\mathrm{H}-\mathrm{H}}=7.3 \mathrm{~Hz}, 3 \mathrm{H}, \mathrm{CH}_{3, \mathrm{n}-\mathrm{Bu}}\right) .{ }^{13} \mathrm{C}\left\{{ }^{1} \mathrm{H}\right\} \mathrm{NMR}\left(100 \mathrm{MHz}, \mathrm{CDCl}_{3}\right): \delta=144.9(\mathrm{C}-4), 129.3$ $(\mathrm{C}-5), 120.6\left(\mathrm{q},{ }^{1} J_{\mathrm{C}-\mathrm{F}}=320.33, \mathrm{CF}_{3}\right), 40.0\left(\mathrm{CH}_{3}-\mathrm{N}\right), 37.4\left(\mathrm{CH}_{3}-\mathrm{N}\right), 28.7\left(\mathrm{CH}_{2}-\mathrm{CH}_{2}\right), 23.0$ $\left(\mathrm{CH}_{2}-\mathrm{CH}_{2}\right), 22.1\left(\mathrm{CH}_{2}-\mathrm{CH}_{3}\right), 13.5\left(\mathrm{CH}_{3}, \mathrm{n}-\mathrm{Bu}\right) .{ }^{19} \mathrm{~F}\left\{{ }^{1} \mathrm{H}\right\} \mathrm{NMR}\left(377 \mathrm{MHz}, \mathrm{CDCl}_{3}\right), \delta$ : 78.53. MS HR-ESI [found 154.1345 (M-OTf) ${ }^{+}, \mathrm{C}_{8} \mathrm{H}_{16} \mathrm{~N}_{3}$ requires 154.1344].

\subsection{Synthesis of Ir-complex 4}

4-Butyl-1,3-dimethyl-1H-1,2,3-triazole trifluoromethanesulfonate $(65 \mathrm{mg}, 0.21$ $\mathrm{mmol}), \mathrm{Me}_{4} \mathrm{NCl}$ (46 mg, $\left.0.42 \mathrm{mmol}\right), \mathrm{Ag}_{2} \mathrm{O}$ (97 mg, $\left.0.42 \mathrm{mmol}\right)$ and $\left[\operatorname{Ir}\left(\mathrm{Cp}^{*}\right) \mathrm{Cl}_{2}\right]_{2}(67$ $\mathrm{mg}, 0.084 \mathrm{mmol}, 0.4$ equiv) were stirred in $\mathrm{CH}_{2} \mathrm{Cl}_{2}(10 \mathrm{ml})$ at $40{ }^{\circ} \mathrm{C}$ for $8 \mathrm{~h}$. After cooling to $\mathrm{rt}$, the suspension was filtered through celite and the solvent was removed under reduced pressure to yield the crude product. Purification by column chromatography $\left(\mathrm{SiO}_{2} ; \mathrm{CH}_{2} \mathrm{Cl}_{2} / \mathrm{MeOH}, 40: 1\right)$ yielded product 4 as yellow solid (12 mg, 10\%). ${ }^{1} \mathrm{H} \mathrm{NMR}$ (400 MHz, $\left.\mathrm{CDCl}_{3}\right): \delta={ }^{1} \mathrm{H}$ NMR $4.27\left(\mathrm{~s}, 3 \mathrm{H}, \mathrm{CH}_{3}-\mathrm{N}\right), 3.96\left(\mathrm{~s}, 3 \mathrm{H}, \mathrm{CH}_{3}-\mathrm{N}\right), 2.95(\mathrm{~m}, 2 \mathrm{H}$, $\left.\mathrm{CH}_{2}-\mathrm{CH}_{2}\right), 2.01-1.74\left(\mathrm{~m}, 1 \mathrm{H}, \mathrm{CH}_{2}-\mathrm{CH}_{2}\right), 1.61$ (s, 15H, Cp*), $1.55-1.18(\mathrm{~m}, 3 \mathrm{H}$, $\left.\mathrm{CH}_{2}-\mathrm{CH}_{2}\right), 0.95\left(\mathrm{t},{ }^{3} J_{\mathrm{H}-\mathrm{H}}=7.1 \mathrm{~Hz}, 3 \mathrm{H}\right) .{ }^{13} \mathrm{C}\left\{{ }^{1} \mathrm{H}\right\} \mathrm{NMR}\left(101 \mathrm{MHz}, \mathrm{CDCl}_{3}\right), \delta: 148.9(\mathrm{C}-5)$, $144.4(\mathrm{C}-4), 87.8\left(\mathrm{C}, \mathrm{Cp}^{*}\right), 40.9\left(\mathrm{CH}_{3}-\mathrm{N}\right), 36.3\left(\mathrm{CH}_{3}-\mathrm{N}\right),, 32.1\left(\mathrm{CH}_{2}\right), 29.8\left(\mathrm{CH}_{2}\right), 23.2$ $\left(\mathrm{CH}_{2}\right), 14.0\left(\mathrm{CH}_{3}, \mathrm{n}-\mathrm{Bu}\right), 9.2\left(\mathrm{CH}_{3}, \mathrm{Cp} *\right)$. MS HR-ESI [found $516.1718(\mathrm{M}-\mathrm{Cl})^{+}$, $\mathrm{C}_{18} \mathrm{H}_{30} \mathrm{ClIr}$ requires 516.1756]. Anal. Calcd for $\mathrm{C}_{18} \mathrm{H}_{30} \mathrm{Cl}_{2} \mathrm{IrN}_{3}: \mathrm{C}, 39.20 ; \mathrm{H}, 5.48 ; \mathrm{N}$, 7.62\%. Found: C, 39.27; H, 5.39; N, 7.65\%.

\subsection{Preparation of dicationic monoaquo complexes 5 and 6}

To a solution of the corresponding Ir-complex $(0.01 \mathrm{mmol})$ in dichloromethane $(1.5$ $\mathrm{mL})$ was sequentially added water $(18 \mu \mathrm{L}, 1.1 \mathrm{mmol})$ and $\operatorname{AgOTf}(3.1 \mathrm{mg}, 1.2 \mathrm{eq})$. The 
reaction was stirred for $12 \mathrm{~h}$ (for compound 5) or $48 \mathrm{~h}$ (compound 6) protected from light. Then the resulting suspension was filtered over celite, and all volatiles were removed under reduced pressure to yield the crude products.

5. Yield: $7.5 \mathrm{mg}, 89 \% .{ }^{1} \mathrm{H}$ NMR (400 MHz, $\left.\mathrm{D}_{2} \mathrm{O}\right), \delta: 8.15\left(\mathrm{~d},{ }^{3} J_{\mathrm{H}-\mathrm{H}}=3.6 \mathrm{~Hz}, 1 \mathrm{H}\right.$, $\mathrm{CH}=), 7.93\left(\mathrm{~d},{ }^{3} J_{\mathrm{H}-\mathrm{H}}=3.6 \mathrm{~Hz}, 1 \mathrm{H}, \mathrm{CH}=\right), 4.29\left(\mathrm{~s}, 3 \mathrm{H}, \mathrm{CH}_{3}-\mathrm{N}\right), 4.28\left(\mathrm{~s}, 3 \mathrm{H}, \mathrm{CH}_{3}-\mathrm{N}\right), 1.61$ (s, 15H, CH $\left.3, \mathrm{Cp}^{*}\right) .{ }^{13} \mathrm{C}\left\{{ }^{1} \mathrm{H}\right\} \mathrm{NMR}\left(101 \mathrm{MHz}, \mathrm{D}_{2} \mathrm{O}\right), \delta: 159.6(\mathrm{C}-5), 157.53(\mathrm{C}=\mathrm{N}), 147.0$ $(\mathrm{C}-4), 141.5(\mathrm{CH}=), 124.8(\mathrm{CH}=), 119.2\left(\mathrm{q},{ }^{1} J_{\mathrm{C}-\mathrm{F}}=320.0, \mathrm{CF}_{3}\right), 90.3(\mathrm{C}, \mathrm{Cp} *), 40.3\left(\mathrm{CH}_{3}-\right.$ $\mathrm{N}), 37.9\left(\mathrm{CH}_{3}-\mathrm{N}\right), 8.6\left(\mathrm{CH}_{3}, \mathrm{Cp}^{*}\right) .{ }^{19} \mathrm{~F}\left\{{ }^{1} \mathrm{H}\right\} \mathrm{NMR}\left(377 \mathrm{MHz}, \mathrm{D}_{2} \mathrm{O}\right), \delta:-79.1$ (s). MS HRESI [found 509.1351 (M-(OTf $\left.)_{2}-\mathrm{H}_{2} \mathrm{O}\right)^{2+}, \mathrm{C}_{17} \mathrm{H}_{24} \mathrm{IrN}_{4} \mathrm{~S}$ requires 509.1345]. Suitable crystals for X-ray diffraction were achieved by slow diffusion of pentane to dichloromethane solution. Crystallographic data have been deposited with the Cambridge Crystallographic Data Centre (CCDC) as supplementary publication number 2003896.

6. Yield: $7.7 \mathrm{mg}, 88 \%$. ${ }^{1} \mathrm{H}$ NMR (400 MHz, $\left.\mathrm{D}_{2} \mathrm{O}\right), \delta$ : 7.73-7.78 (m, 2H, $\left.\mathrm{CH}=\right), 7.52$ $(\mathrm{m}, 2 \mathrm{H}, \mathrm{CH}=), 4.38\left(\mathrm{~s}, 3 \mathrm{H}, \mathrm{CH}_{3}-\mathrm{N}\right), 4.32\left(\mathrm{~s}, 3 \mathrm{H}, \mathrm{CH}_{3}-\mathrm{N}\right), 1.67$ (s, 15H, $\left.\mathrm{CH}_{3}, \mathrm{Cp}^{*}\right)$. ${ }^{13} \mathrm{C}\left\{{ }^{1} \mathrm{H}\right\} \operatorname{NMR}\left(101 \mathrm{MHz}, \mathrm{D}_{2} \mathrm{O}\right), \delta: 156.8(\mathrm{C}-5), 151.5(\mathrm{C}=\mathrm{N}), 135.9(\mathrm{C}-4), 128.1(\mathrm{CH}=)$, $127.3(\mathrm{CH}=), 120.0\left(\mathrm{q},{ }^{1} J_{\mathrm{C}-\mathrm{F}}=210.2, \mathrm{CF}_{3}\right), 90.8\left(\mathrm{C}, \mathrm{Cp}^{*}\right), 40.8\left(\mathrm{CH}_{3}-\mathrm{N}\right), 38.3\left(\mathrm{CH}_{3}-\mathrm{N}\right)$, $9.2\left(\mathrm{CH}_{3}, \mathrm{Cp}^{*}\right) .{ }^{19} \mathrm{~F}\left\{{ }^{1} \mathrm{H}\right\}$ NMR $\left(377 \mathrm{MHz}, \mathrm{D}_{2} \mathrm{O}\right), \delta:-79.1(\mathrm{~s})$.

\subsection{Preparation of dicationic diaquo complex 7}

Monoaquo complex $6(0.01 \mathrm{mmol})$ was dissolved in $\mathrm{D}_{2} \mathrm{O}(1 \mathrm{~mL})$ and allowed to stir at $70{ }^{\circ} \mathrm{C}$ for 3 days. $85 \%$ yield by ${ }^{1} \mathrm{H}$ NMR. ${ }^{1} \mathrm{H}$ NMR (400 MHz, $\left.\mathrm{D}_{2} \mathrm{O}\right), \delta: 6.98(\mathrm{~m}, 2 \mathrm{H}$, $\mathrm{CH}=), 6.86(\mathrm{~m}, 2 \mathrm{H}, \mathrm{CH}=), 4.17\left(\mathrm{~s}, 3 \mathrm{H}, \mathrm{CH}_{3}-\mathrm{N}\right), 4.08\left(\mathrm{~s}, 3 \mathrm{H}, \mathrm{CH}_{3}-\mathrm{N}\right), 1.27\left(\mathrm{~s}, 15 \mathrm{H}, \mathrm{CH}_{3}\right.$, Cp*). ${ }^{13} \mathrm{C}\left\{{ }^{1} \mathrm{H}\right\}$ NMR (101 MHz, $\left.\mathrm{D}_{2} \mathrm{O}\right), \delta: 166.6(\mathrm{C}-5), 149.9(\mathrm{C}=\mathrm{N}), 144.4(\mathrm{C}-4), 136.4$ (C), $128.0(\mathrm{CH}=), 127.2(\mathrm{CH}=), 126.5(\mathrm{CH}=), 119.2\left(\mathrm{q},{ }^{1} J_{\mathrm{C}-\mathrm{F}}=260.7, \mathrm{CF}_{3}\right), 116.1(\mathrm{CH}=)$, $88.7\left(\mathrm{C}, \mathrm{Cp}^{*}\right), 39.6\left(\mathrm{CH}_{3}-\mathrm{N}\right), 35.8\left(\mathrm{CH}_{3}-\mathrm{N}\right), 8.1\left(\mathrm{CH}_{3}, \mathrm{Cp}^{*}\right) .{ }^{19} \mathrm{~F}\left\{{ }^{1} \mathrm{H}\right\} \mathrm{NMR}(377 \mathrm{MHz}$, $\left.\mathrm{D}_{2} \mathrm{O}\right), \delta:-79.0(\mathrm{~s})$.

\subsection{Preparation of dicationic diaquo complex 8}

To a solution of Ir-complex 4 (10 $\mathrm{mg}, 0.018 \mathrm{mmol})$ in dichloromethane $(1.5 \mathrm{~mL})$ was sequentially added water $(18 \mu \mathrm{L}, 1.1 \mathrm{mmol})$ and $\operatorname{AgOTf}(9.2 \mathrm{mg}, 2$ eq). The reaction was stirred for $18 \mathrm{~h}$ protected from light. Then the resulting suspension was filtered over celite, and all volatiles were removed under reduced pressure to yield the crude product. Yield: $8.0 \mathrm{mg}, 62 \%$. ${ }^{1} \mathrm{H}$ NMR (400 MHz, $\left.\mathrm{D}_{2} \mathrm{O}\right), \delta: 4.09$ (s, 3H, $\left.\mathrm{CH}_{3}-\mathrm{N}\right), 4.04$ (s, 3H, $\left.\mathrm{CH}_{3}-\mathrm{N}\right)$, 2.79 (broad s, $1 \mathrm{H}, \mathrm{CH}_{2}-\mathrm{CH}_{2}$ ), 2.65 (broad s, $1 \mathrm{H}, \mathrm{CH}_{2}-\mathrm{CH}_{2}$ ), 1.57 (s, $17 \mathrm{H}, \mathrm{Cp}^{*}, \mathrm{CH}_{2}-\mathrm{CH}_{2}$ ), 
$1.44\left(\mathrm{~m}, 2 \mathrm{H}, \mathrm{CH}_{2}-\mathrm{CH}_{2}\right), 0.93\left(\mathrm{t},{ }^{1} J_{\mathrm{H}-\mathrm{H}}=7.3 \mathrm{~Hz}, 3 \mathrm{H}, \mathrm{CH}_{3}\right) .{ }^{13} \mathrm{C}\left\{{ }^{1} \mathrm{H}\right\} \mathrm{NMR}(100 \mathrm{MHz}$, $\left.\mathrm{D}_{2} \mathrm{O}\right), \delta: 148.0(\mathrm{C}-5), 147.1(\mathrm{C}-4), 119.4\left(\mathrm{q},{ }^{1} J_{\mathrm{C}-\mathrm{F}}=317.2, \mathrm{CF}_{3}\right), 87.6\left(\mathrm{C}, \mathrm{Cp}^{*}\right), 39.6\left(\mathrm{CH}_{3}-\right.$ $\mathrm{N}), 36.4\left(\mathrm{CH}_{3}-\mathrm{N}\right), 30.2\left(\mathrm{CH}_{2}\right), 23.9\left(\mathrm{CH}_{2}\right), 22.2\left(\mathrm{CH}_{2}\right), 12.7\left(\mathrm{CH}_{3}, \mathrm{n}-\mathrm{Bu}\right), 8.3\left(\mathrm{CH}_{3}\right.$, $\mathrm{Cp} *) .{ }^{19} \mathrm{~F}\left\{{ }^{1} \mathrm{H}\right\}$ NMR $\left(376 \mathrm{MHz}, \mathrm{D}_{2} \mathrm{O}\right), \delta:-78.9$ (s).

\subsection{Preparation of iodide complexes 9 and 10}

To a solution of Ir-complex 1 or $\mathbf{2}(0.01 \mathrm{mmol})$ in dichloromethane $(1.5 \mathrm{~mL})$ was added $\mathrm{NaI}(1.7 \mathrm{mg}, 1.1 \mathrm{eq})$. The reaction was stirred overnight at room temperature. Then water was added and the aqueous phase was extracted with DCM three times. After drying over $\mathrm{MgSO}_{4}$, the volatiles were removed under reduced pressure to yield the crude product.

9. Yield: $7.7 \mathrm{mg}, 94 \% .{ }^{1} \mathrm{H} \mathrm{NMR}\left(400 \mathrm{MHz}, \mathrm{CDCl}_{3}\right), \delta: 7.80-7.28(\mathrm{~m}, 4 \mathrm{H}, \mathrm{CH}=)$, 4.59 (s, 3H, CH3 $-\mathrm{N}), 4.26$ (s, 3H, CH $\left.\mathrm{CH}_{3} \mathrm{~N}\right), 2.03$ (s, 15H, CH $\left.3, \mathrm{Cp}^{*}\right) .{ }^{13} \mathrm{C}\left\{{ }^{1} \mathrm{H}\right\} \mathrm{NMR}(100$ $\left.\mathrm{MHz}, \mathrm{CDCl}_{3}\right), \delta: 159.1(\mathrm{C}-5), 157.8(\mathrm{C}=\mathrm{N}), 150.6(\mathrm{C}=), 137.5(\mathrm{C}=), 136.3(\mathrm{C}-4), 127.7$ $(\mathrm{CH}=), 126.8(\mathrm{CH}=), 117.3(\mathrm{CH}=), 113.4(\mathrm{CH}=), 91.2\left(\mathrm{C}, \mathrm{Cp}^{*}\right), 40.9\left(\mathrm{CH}_{3}-\mathrm{N}\right), 31.9$ $\left(\mathrm{CH}_{3}-\mathrm{N}\right), 11.8\left(\mathrm{CH}_{3}, \mathrm{Cp} *\right) .{ }^{19} \mathrm{~F}\left\{{ }^{1} \mathrm{H}\right\}$ NMR $\left(376 \mathrm{MHz}, \mathrm{CDCl}_{3}\right), \delta:-78.5$ (s). MS HR-ESI [found $669.0677(\mathrm{M})^{+}, \quad \mathrm{C}_{21} \mathrm{H}_{25} \mathrm{IIrN}_{4} \mathrm{O}^{+}$requires 669.0679]. Anal. Calcd for $\mathrm{C}_{22} \mathrm{H}_{25} \mathrm{~F}_{3} \mathrm{IIrN}_{4} \mathrm{O}_{4} \mathrm{~S}$ : C, 32.32; H, 3.08; N, 6.85\%. Found: C, 32.28; H, 3.07; N, 6.79\%.

10. Yield: $7.1 \mathrm{mg}, 91 \% .{ }^{1} \mathrm{H}$ NMR (400 MHz, $\left.\mathrm{CDCl}_{3}\right), \delta: 7.92\left(\mathrm{~d},{ }^{3} J_{\mathrm{H}-\mathrm{H}}=3.5 \mathrm{~Hz}, 1 \mathrm{H}\right.$, $\mathrm{CH}=), 7.68\left(\mathrm{~d},{ }^{3} J_{\mathrm{H}-\mathrm{H}}=3.5 \mathrm{~Hz}, 1 \mathrm{H}, \mathrm{CH}=\right), 4.51\left(\mathrm{~s}, 3 \mathrm{H}, \mathrm{CH}_{3}-\mathrm{N}\right), 4.28\left(\mathrm{~s}, 3 \mathrm{H}, \mathrm{CH}_{3}-\mathrm{N}\right), 1.97$ (s, $\left.15 \mathrm{H}, \mathrm{CH}_{3}, \mathrm{Cp}^{*}\right) .{ }^{13} \mathrm{C}\left\{{ }^{1} \mathrm{H}\right\}$ NMR $\left(100 \mathrm{MHz}, \mathrm{CDCl}_{3}\right), \delta: 157.0(\mathrm{C}-5), 156.0(\mathrm{C}=\mathrm{N})$, $144.2(\mathrm{C}-4), 141.5(\mathrm{C}=), 122.5(\mathrm{C}=), 91.6\left(\mathrm{C}, \mathrm{Cp}^{*}\right), 39.9\left(\mathrm{CH}_{3}-\mathrm{N}\right), 38.9\left(\mathrm{CH}_{3}-\mathrm{N}\right), 10.5$ $\left(\mathrm{CH}_{3}, \mathrm{Cp} *\right) .{ }^{19} \mathrm{~F}\left\{{ }^{1} \mathrm{H}\right\}$ NMR (376 MHz, $\left.\mathrm{CDCl}_{3}\right), \delta:-78.5$ (s). MS HR-ESI [found 635.0316 $(\mathrm{M})^{+}, \mathrm{C}_{17} \mathrm{H}_{23} I \mathrm{IrN}_{4} \mathrm{~S}^{+}$requires 635.0318]. Anal. Calcd for $\mathrm{C}_{18} \mathrm{H}_{23} \mathrm{~F}_{3} \mathrm{IIrN}_{4} \mathrm{O}_{3} \mathrm{~S}_{2}$ : C, 27.59; H, 2.96; N, 7.15\%. Found: C, 27.51; H, 2.94; N, 7.06\%.

\subsection{Preparation of diiodide complexes 11 and 12}

To a solution of Ir-complex $9(7.7 \mathrm{mg}, 0.009 \mathrm{mmol})$ or $\mathbf{1 0}(7.1 \mathrm{mg}, 0.009 \mathrm{mmol})$ in dichloromethane $(1.5 \mathrm{~mL})$ was added $\mathrm{NaI}(1.7 \mathrm{mg}, 1.1 \mathrm{eq})$. The reaction was stirred overnight at room temperature. Then water was added and the aqueous phase was extracted with DCM three times. After drying over $\mathrm{MgSO}_{4}$, the volatiles were removed under reduced pressure to yield the crude product.

11. Yield: $6.9 \mathrm{mg}, 90 \% .{ }^{1} \mathrm{H}$ NMR (400 $\left.\mathrm{MHz}, \mathrm{CDCl}_{3}\right), \delta: 7.80-7.28(\mathrm{~m}, 4 \mathrm{H}, \mathrm{CH}=)$, 4.40 (s, 3H, CH $\left.\mathrm{CH}_{3}-\mathrm{N}\right), 4.14$ (s, 3H, CH $\left.\mathrm{CH}_{3} \mathrm{~N}\right), 1.88$ (s, 15H, $\left.\mathrm{CH}_{3}, \mathrm{Cp}^{*}\right) .{ }^{13} \mathrm{C}\left\{{ }^{1} \mathrm{H}\right\} \mathrm{NMR}(100$ $\left.\mathrm{MHz}, \mathrm{CDCl}_{3}\right), \delta: 152.8(\mathrm{C}-5), 151.5(\mathrm{C}=\mathrm{N}), 141.2(\mathrm{C}=), 137.5(\mathrm{C}=), 135.4(\mathrm{C}-4), 126.0$ 
$(\mathrm{CH}=), 124.8(\mathrm{CH}=), 120.7(\mathrm{CH}=), 110.9(\mathrm{CH}=), 88.5\left(\mathrm{C}, \mathrm{Cp}^{*}\right), 41.4\left(\mathrm{CH}_{3}-\mathrm{N}\right), 31.4$ $\left(\mathrm{CH}_{3}-\mathrm{N}\right), 9.4\left(\mathrm{CH}_{3}, \mathrm{Cp}^{*}\right)$. MS HR-ESI [found $669.0677(\mathrm{M})^{+}, \mathrm{C}_{21} \mathrm{H}_{25} \mathrm{IIrN}_{4} \mathrm{O}^{+}$requires 669.0679]. Anal. Calcd for $\mathrm{C}_{21} \mathrm{H}_{25} \mathrm{I}_{2} \mathrm{IrN}_{4} \mathrm{O}$ : C, 31.71; H, 3.17; N, 7.04\%. Found: C, 31.65; H, 3.15; N, 6.99\%.

12. Yield: $6.2 \mathrm{mg}, 89 \% .{ }^{1} \mathrm{H} \mathrm{NMR}\left(400 \mathrm{MHz}, \mathrm{CDCl}_{3}\right), \delta$ : $7.92\left(\mathrm{~d},{ }^{3} J_{\mathrm{H}-\mathrm{H}}=3.5 \mathrm{~Hz}, 1 \mathrm{H}\right.$, $\mathrm{CH}=), 7.72\left(\mathrm{~d},{ }^{3} J_{\mathrm{H}-\mathrm{H}}=3.5 \mathrm{~Hz}, 1 \mathrm{H}, \mathrm{CH}=\right), 4.54\left(\mathrm{~s}, 3 \mathrm{H}, \mathrm{CH}_{3}-\mathrm{N}\right), 4.31\left(\mathrm{~s}, 3 \mathrm{H}, \mathrm{CH}_{3}-\mathrm{N}\right), 2.00$ (s, $\left.15 \mathrm{H}, \mathrm{CH}_{3}, \mathrm{Cp}^{*}\right)$. MS HR-ESI [found $635.0307(\mathrm{M})^{+}, \mathrm{C}_{17} \mathrm{H}_{23} \operatorname{IIrN}_{4} \mathrm{~S}^{+}$requires 635.0318]. Anal. Calcd for $\mathrm{C}_{17} \mathrm{H}_{23} \mathrm{I}_{2} \mathrm{IrN}_{4} \mathrm{~S}$ : C, 26.81; H, 3.04; N, 7.36\%. Found: C, 26.73; $\mathrm{H}, 3.02 ; \mathrm{N}, 7.28 \%$.

\subsection{Electrochemistry}

Cyclic voltammetry (CV) and differential pulse voltammetry (DPV) experiments were performed on a Biologic SP-150 potentiostat, using EC Lab software for data acquisition and data handling. Measurements were made using a standard three-electrode cell using glassy carbon disk electrode of $3.0 \mathrm{~mm}$ diameter as a working electrode, a Pt disk of 1 $\mathrm{mm}$ diameter as counter electrode and an aqueous saturated calomel electrode (SCE) as a reference electrode. All of the potentials are reported versus SCE isolated from the working electrode compartment by a salt bridge. Working electrodes were polished with 1 and 0.05 micron Alumina paste washed with distilled water and acetone and sonicated in acetone for 5 minutes before each measurement. The complexes were dissolved in $\mathrm{CH}_{2} \mathrm{Cl}_{2}$ containing the necessary amount of $\left(\mathrm{Bu}_{4} \mathrm{~N}\right) \mathrm{PF}_{6}\left(\mathrm{TBAPF}_{6}\right)$ as supporting electrolyte to yield $0.1 \mathrm{M}$ ionic strength solutions. For electrocatalytic experiments, complexes were dissolved in the corresponding water solutions ( $0.1 \mathrm{M}$ triflic acid solution or acetate buffer $\mathrm{pH} 5.6)$. $\mathrm{CV}$ were recorded at different scan rates $(50-1000 \mathrm{mV} / \mathrm{s})$ and DPV were recorded using pulse amplitudes of $0.05 \mathrm{~V}$, pulse widths of $0.05 \mathrm{~s}$, sampling widths of $0.02 \mathrm{~s}$, pulse periods of $0.1 \mathrm{~s}$ and quite times of $2 \mathrm{~s}$. E0 values reported in this work were estimated from DPV experiments. The error associated with the potential values is less than $5 \mathrm{mV}$.

\subsection{Typical procedure for the water oxidation}

Catalysis experiments were performed in a homemade thermostated glass cell (V $=15$ $\mathrm{mL})$ at $25^{\circ} \mathrm{C}$ which was closed with a septum. The evolution of gases were monitored by on-line manometry with a differential pressure manometer (Testo 521), with an operating range of $0.1-10 \mathrm{kPa}$ and accuracy within $0.5 \%$, which was connected to a reference cell 
of approximately the same size, as well as by a gas phase oxygen sensor (Unisense Ox-N sensor) controlled by Unisense multimeter. The oxygen sensor was calibrated after each experiment by addition of known amounts of oxygen to the cell. Manometric and $\mathrm{O}_{2}$ selective Clark-type experiments were performed in duplicate with errors between measurements consistently $<10 \%$. Complexes 1-4 were recrystallized and exhaustively dried under vacuum prior to use.

In a typical experiment, a solution of complex in $0.1 \mathrm{M}$ triflic acid ( $\mathrm{pH} 1)$ was degassed for 10 minutes using $\mathrm{N}_{2}$ flow. After pressure equilibration between reference and measurement cell, baseline was recorded for 20-30 minutes and a solution of cerium ammonium nitrate $(\mathrm{CAN})$ in $0.1 \mathrm{M}$ Triflic acid was added to the reference and measurement cell. Resulting a final concentration of catalyst $1 \mathrm{mM}$ and concentration of CAN $100 \mathrm{mM}$. For second and third injections, this procedure was carried out again adding 100 more equivalents of CAN in $0.1 \mathrm{M}$ Triflic acid to the measurement and reference cells. Experiments with $\mathrm{NaIO}_{4}$ were performed by using diluted degassed solutions of the complex in $0.1 \mathrm{M} \mathrm{NaOAc}(\mathrm{pH} 5.6)$ or $0.1 \mathrm{M}$ phosphate buffer $(\mathrm{pH} 7)$ under an otherwise identical setup, resulting a final catalyst/oxidant ratio of varying from 1:50 to $1: 4000$ and a final concentration $5 \mu \mathrm{M}$ for the catalyst and $20 \mathrm{mM}$ for the $\mathrm{NaIO}_{4}$.

TON was calculated from $\mathrm{O}_{2}$-selective Clark-electrode analysis of the reaction headspace and TOF values were calculated from the increase of TON in the initial 5 minutes after addition of oxidant. $\mathrm{O}_{2} / \mathrm{Gas}$ ratios were calculated dividing total oxygen produced detected by $\mathrm{O}_{2}$-selective clark probe by the total gas evolved obtained by manometric experiments.

\section{Acknowledgements}

We gratefully acknowledge financial support from the Spanish Ministry of Economy and Competitiveness (CTQ2016-74878-P and PID2019-104904GB-I00), European Regional Development Fund (AEI/FEDER, UE), the Catalan Government (2017SGR1472), the ICREA Foundation (ICREA Academia award to M.D), MINECO/FEDER (CTQ201680058-R and CTQ2015-64261-R), the European Research Council (CoG 615653), and the Swiss National Science Foundation (200020-182663). The research leading to these results has received funding from "La Caixa" Foundation.

\section{Associated Content}


Copies of NMR spectra of complexes 4-12. Reactivity studies towards water and in acid media. Electrochemical characterization in organic solvents. Water oxidation catalysis using $\mathrm{CAN}$ and $\mathrm{NaIO}_{4}$.

\section{References}

${ }^{1}$ International Energy Agency: World Energy Outlook, 2015.

${ }^{2}$ See for instance: (a) Lewis, N. S.; Crabtree, G. Basic Research Needs for Solar Energy Utilization: Report of the Basic Energy Sciences Workshop on Solar Energy Utilization, Apr 18-21, 2005. US Department of Energy Office of Basic Energy Sciences, 2005. (b) Lewis, N. S.; Nocera, D. G. Powering the planet: Chemical challenges in solar energy utilization. Proc. Natl. Acad. Sci. 2006, 103, 15729-15735. (c) Gray, H. B. Powering the planet with solar fuel. Nat. Chem. 2009, 1, 7.

${ }^{3}$ For recent reviews, see: (a) Molecular Water Oxidation Catalysis; Ed. Llobet, A., Wiley, Chichester, 2005. (b) Kärkäs, M. D.; Verho, O.; Johnston, E. V.; Åkermark, B. Artificial Photosynthesis: Molecular Systems for Catalytic Water Oxidation. Chem Rev. 2014, 114, 11863-12001. (c) Blakemore, J. D.; Crabtree, R. H.; Brudvig, G. W. Molecular Catalysts for Water Oxidation. Chem. Rev. 2015, 115, 12974-13005. (d) Hunter, B. M.; Gray, H. B.; Müller, A. M. Earth-Abundant Heterogeneous Water Oxidation Catalysts. Chem. Rev. 2016, 116, 14120-14136.

${ }^{4}$ For representative examples, see: (a) Gersten, S. W.; Samuels, G. J.; Meyer, T. J. Catalytic oxidation of water by an oxo-bridged ruthenium dimer. J. Am. Chem. Soc. 1982, 104, 4029-4030. (b) Sens, C.; Romero, I.; Rodríguez, M.; Llobet, A.; Parella, T.; BenetBuchholz, J. A New Ru Complex Capable of Catalytically Oxidizing Water to Molecular Dioxygen. J. Am. Chem. Soc. 2004, 126, 7798-7799. (c) Xu, Y.; Fischer, A.; Duan, L.; Tong, L.; Gabrielsson, E.; Åkermark, B.; Sun, L. Chemical and Light-Driven Oxidation of Water Catalyzed by an Efficient Dinuclear Ruthenium Complex. Angew. Chem., Int. Ed. 2010, 49, 8934-8937. (d) Zong, R.; Thummel, R. P. A New Family of Ru Complexes for Water Oxidation. J. Am. Chem. Soc. 2005, 127, 12802-12803. (e) Nyhlén, J.; Duan, L.; Åkermark, B.; Sun, L.; Privalov, T. Evolution of $\mathrm{O}_{2}$ in a seven-coordinate $\mathrm{Ru}(\mathrm{IV})$ dimer complex with a $[\mathrm{HOHOH}]^{-}$bridge: a computational study. Angew. Chem., Int. Ed. 2010, 49, 1773-1777. (f) Duan, L.-L.; Xu, Y.-H.; Tong, L.-P.; Sun, L.-C. Ce(IV)- and light-driven water oxidation by $\left[\mathrm{Ru}(\text { terpy })(\text { pic })_{3}\right]^{2+}$ analogues: catalytic and mechanistic studies. ChemSusChem 2011, 4, 238-244. (g) Kärkäs, M. D.; Åkermark, T.; Johnston, E. 
V.; Karim, S. R.; Laine, T. M.; Lee, B.-L.; Åkermark, T.; Privalov, T.; Åkermark, B. Water Oxidation by Single-Site Ruthenium Complexes: Using Ligands as Redox and Proton Transfer Mediators. Angew. Chem., Int. Ed. 2012, 51, 11589-11593. (h) Duan, L.; Bozoglian, F.; Mandal, S.; Stewart, B.; Privalov, T.; Llobet, A.; Sun, L. A molecular ruthenium catalyst with water-oxidation activity comparable to that of photosystem II. Nat. Chem. 2012, 4, 418-423. (i) Matheu, R.; Ertem, M. Z.; Benet-Buchholz, J.; Coronado, E.; Batista, V. S.; Sala, X.; Llobet, A. Intramolecular Proton Transfer Boosts Water Oxidation Catalyzed by a Ru Complex. J. Am. Chem. Soc. 2015, 137, 1078610795. (j) Creus, J.; Matheu, R.; Peñafiel, I.; Moonshiram, D.; Blondeau, P.; BenetBuchholz, J.; García-Antón, J.; Sala, X.; Godard, C.; Llobet, A. A Million Turnover Molecular Anode for Catalytic Water Oxidation. Angew. Chem., Intl. Ed. 2016, 55, 15382-15386. (k) Matheu, R.; Ertem, M. Z.; Gimbert-Suriñach, C.; Sala, X.; Llobet. A. Seven Coordinated Molecular Ruthenium-Water Oxidation Catalysts: A Coordination Chemistry Journey. Chem. Rev. 2019, 119, 3453-3471.

${ }^{5}$ For representative examples, see: (a) Naruta, Y.; Sasayama, M.-A.; Sasaki, T. Oxygen Evolution by Oxidation of Water with Manganese Porphyrin Dimers. Angew. Chem., Int. Ed. Engl. 1994, 33, 1839-1841. (b) Limburg, J.; Brudvig, G. W.; Crabtree, R. H. O Evolution and Permanganate Formation from High-Valent Manganese Complexes. J. Am. Chem. Soc. 1997, 119, 2761-2762. (c) Limburg, J.; Vrettos, J. S.; Liable-Sands, L. M.; Rheingold, A. L.; Crabtree, R. H.; Brudvig, G. W. A Functional Model for O-O Bond Formation by the $\mathrm{O}_{2}$-Evolving Complex in Photosystem II. Science 1999, 283, 1524 1527. (d) Chen, H.; Faller, J. W.; Crabtree, R. H.; Brudvig, G. W. Dimer-of-Dimers Model for the Oxygen-Evolving Complex of Photosystem II. Synthesis and Properties of $\left[\mathrm{Mn}^{\mathrm{IV}}{ }_{4} \mathrm{O}_{5}(\text { terpy })_{4}\left(\mathrm{H}_{2} \mathrm{O}\right)_{2}\right]\left(\mathrm{ClO}_{4}\right)_{6}$. J. Am. Chem. Soc. 2004, 126, 7345-7349. (e) Shimazaki, Y.; Nagano, T.; Takesue, H.; Ye, B.-H.; Tani, F.; Naruta, Y. Characterization of a Dinuclear $\mathrm{Mn}^{\mathrm{V}}=\mathrm{O}$ Complex and Its Efficient Evolution of $\mathrm{O}_{2}$ in the Presence of Water. Angew. Chem., Int. Ed. 2004, 43, 98-100. (f) Poulsen, A. K.; Rompel, A.; McKenzie, C. J. Water oxidation catalyzed by a dinuclear Mn complex: a functional model for the oxygen-evolving center of photosystem II. Angew. Chem., Int. Ed. 2005, 44, 6916-6920. (g) Anderlund, M. F.; Högblom, J.; Shi, W.; Huang, P.; Eriksson, L.; Weihe, H.; Styring, S.; Åkermark, B.; Lomoth, R.; Magnuson, A. Redox Chemistry of a Dimanganese(II,III) Complex with an Unsymmetric Ligand: Water Binding, Deprotonation and Accumulative Light-Induced Oxidation. Eur. J. Inorg. Chem. 2006, 5033-5047. (h) Brimblecombe, R.; Swiegers, G. F.; Dismukes, G. C.; Spiccia, L. 
Sustained water oxidation photocatalysis by a bioinspired manganese cluster. Angew. Chem., Int. Ed. 2008, 47, 7335-7338. (i) Herrero, C.; Hughes, J. L.; Quaranta, A.; Cox, N.; Rutherford, A. W.; Leibl, W.; Aukauloo, A. Intramolecular light induced activation of a Salen-Mn ${ }^{\mathrm{III}}$ complex by a ruthenium photosensitizer. Chem. Commun. 2010, 46, 7605-7607. (j) Brimblecombe, R.; Koo, A.; Dismukes, G. C.; Swiegers, G. F.; Spiccia, L. Solar Driven Water Oxidation by a Bioinspired Manganese Molecular Catalyst. J. Am. Chem. Soc. 2010, 132, 2892-2894.

${ }^{6}$ For representative examples, see: (a) McDaniel, N. D.; Coughlin, F. J.; Tinker, L. L.; Bernhard, S. Cyclometalated Iridium(III) Aquo Complexes: Efficient and Tunable Catalysts for the Homogeneous Oxidation of Water. J. Am. Chem. Soc. 2008, 130, 210217. (b) Hull, J. F.; Balcells, D.; Blakemore, J. D.; Incarvito, C. D.; Eisenstein, O.; Brudvig, G. W.; Crabtree, R. H. Highly Active and Robust Cp* Iridium Complexes for Catalytic Water Oxidation. J. Am. Chem. Soc. 2009, 131, 8730-8731. (c) Savini, A.; Bellachioma, G.; Ciancaleoni, G.; Zuccaccia, C.; Zuccaccia, D.; Macchioni, A. Iridium(III) molecular catalysts for water oxidation: the simpler the faster. Chem. Commun. 2010, 46, 9218-9219. (d) Lalrempuia, R.; McDaniel, N. D.; Müller-Bunz, H.; Bernhard, S.; Albrecht, M. Water oxidation catalyzed by strong carbene-type donorligand complexes of iridium. Angew. Chem., Int. Ed. 2010, 49, 9765-9768. (e) Grotjahn, D. B.; Brown, D. B.; Martin, J. K.; Marelius, D. C.; Abadjian, M.-C.; Tran, H. N.; Kalyuzhny, G.; Vecchio, K. S.; Specht, Z. G.; Cortes-Llamas, S. A.; Miranda-Soto, V.; van Niekerk, C.; Moore, C. E.; Rheingold, A. L. Evolution of Iridium-Based Molecular Catalysts during Water Oxidation with Ceric Ammonium Nitrate. J. Am. Chem. Soc. 2011, 133, 19024-19027. (f) Parent, A. R.; Blakemore, J. D.; Brudvig, G. W.; Crabtree, R. H. Wilkinson's iridium acetate trimer as a water-oxidation catalyst. Chem. Commun. 2011, 47, 11745-11747. (g) Codola, Z.; Cardoso, J. M. S.; Royo, B.; Costas, M.; LloretFillol, J. Highly Effective Water Oxidation Catalysis with Iridium Complexes through the Use of $\mathrm{NaIO}_{4}$. Chem. Eur. J. 2013, 19, 7203-7213. (h) Turlington, C. R.; White, P. S.; Brookhart, M.; Templeton, J. L. Oxygen Atom Transfer to a Half-Sandwich Iridium Complex: Clean Oxidation Yielding a Molecular Product. J. Am. Chem. Soc. 2014, 136, 3981-3994. (i) Navarro, M.; Li, M.; Mueller-Bunz, H.; Bernhard, S.; Albrecht, M. DonorFlexible Nitrogen Ligands for Efficient Iridium-Catalyzed Water Oxidation Catalysis. Chem. Eur. J. 2016, 22, 6740-6745. (j) Sharninghausen, L. S.; Sinha, S. B.; Shopov, D. Y.; Choi, B.; Mercado, B. Q.; Roy, X.; Balcells, D.; Brudvig, G. W.; Crabtree, R. H. High Oxidation State Iridium Mono- $\mu$-oxo Dimers Related to Water Oxidation Catalysis. $J$. 
Am. Chem. Soc. 2016, 138, 15917-15926. (k) Rodríguez, G. M.; Gatto, G.; Zuccaccia, C.; Macchioni, A. Benchmarking Water Oxidation Catalysts Based on Iridium Complexes: Clues and Doubts on the Nature of Active Species. ChemSusChem 2017, 10, 4503-4509. (1) Puerta-Oteo, R.; Jiménez, M. V.; Pérez-Torrente, J. J. Molecular water oxidation catalysis by zwitterionic carboxylate bridge-functionalized bis-NHC iridium complexes. Catal. Sci. Technol. 2019, 9, 1437-1450.

${ }^{7}$ For representative examples, see: (a) Abe, T.; Nagai, K.; Kabutomori, S.; Kaneko, M.; Tajiri, A.; Norimatsu, T. An organic photoelectrode working in the water phase: visiblelight-induced dioxygen evolution by a perylene derivative/cobalt phthalocyanine bilayer. Angew. Chem., Int. Ed. Engl. 2006, 45, 2778-2781. (b) Rigsby, M. L.; Mandal, S.; Nam, W.; Spencer, L. C.; Llobet, A.; Stahl, S. S. Cobalt analogs of Ru-based water oxidation catalysts: overcoming thermodynamic instability and kinetic lability to achieve electrocatalytic $\mathrm{O}_{2}$ evolution. Chem. Sci. 2012, 3, 3058-3062. (c) Berardi, S.; La Ganga, G.; Natali, M.; Bazzan, I.; Puntoriero, F.; Sartorel, A.; Scandola, F.; Campagna, S.; Bonchio, M. Photocatalytic Water Oxidation: Tuning Light-Induced Electron Transfer by Molecular $\mathrm{Co}_{4} \mathrm{O}_{4}$ Cores. J. Am. Chem. Soc. 2012, 134, 11104-11107. (d) Lv, H.; Song, J.; Geletii, Y. V.; Vickers, J. W.; Sumliner, J. M.; Musaev, D. G.; Kögerler, P.; Zhuk, P. F.; Bacsa, J.; Zhu, G.; Hill, C. L. An Exceptionally Fast Homogeneous Carbon-Free Cobalt-Based Water Oxidation Catalyst. J. Am. Chem. Soc. 2014, 136, 9268-9271. (e) Zhang, B.; Li, F.; Yu, F.; Wang, X.; Zhou, X.; Li, H.; Jiang, Y.; Sun, L. Electrochemical and Photoelectrochemical Water Oxidation by Supported Cobalt-Oxo Cubanes. ACS Catal. 2014, 4, 804-809. (f) Moonshiram, D.; Gimbert-Suriñach, C.; Guda, A.; Picon, A.; Lehmann, C. S.; Zhang, Z.; Doumy, G.; March, A. M.; Benet-Buchholz, J.; Soldatov, A.; Llobet, A.; Southworth, S. H. Tracking the Structural and Electronic Configurations of a Cobalt Proton Reduction Catalyst in Water. J. Am. Chem. Soc. 2016, 138, 10586-10596. ${ }^{8}$ For representative examples, see: (a) Ellis, W. C.; McDaniel, N. D.; Bernhard, S.; Collins, T. J. Fast Water Oxidation Using Iron. J. Am. Chem. Soc. 2010, 132, 1099010991. (b) Fillol, J. L.; Codola, Z.; Garcia-Bosch, I.; Gomez, L.; Pla, J. J.; Costas, M. Efficient water oxidation catalysts based on readily available iron coordination complexes. Nat. Chem. 2011, 3, 807-813. (c) Chen, G.; Chen, L.; Ng, S.-M.; Man, W.L.; Lau, T.-C. Chemical and visible-light-driven water oxidation by iron complexes at $\mathrm{pH}$ 7-9: evidence for dual-active intermediates in iron-catalyzed water oxidation. Angew. Chem., Int. Ed. 2013, 52, 1789-1791. (d) Demeter, E. L.; Hilburg, S. L.; Washburn, N. R.; Collins, T. J.; Kitchin, J. R. Electrocatalytic Oxygen Evolution with an Immobilized 
TAML Activator. J. Am. Chem. Soc. 2014, 136, 5603-5606. (e) Panda, C.; Debgupta, J.; Diaz Diaz, D.; Singh, K. K.; Sen Gupta, S.; Dhar, B. B. Homogeneous Photochemical Water Oxidation by Biuret-Modified Fe-TAML: Evidence of $\mathrm{FeV}(\mathrm{O})$ Intermediate. $J$. Am. Chem. Soc. 2014, 136, 12273-12282. (f) Coggins, M. K.; Zhang, M.-T.; Vannucci, A. K.; Dares, C. J.; Meyer, T. J. Electrocatalytic Water Oxidation by a Monomeric Amidate-Ligated Fe(III)-Aqua Complex. J. Am. Chem. Soc. 2014, 136, 5531-5534.

${ }^{9}$ For recent reviews, see: (a) Corbucci, I.; Macchioni, A.; Albrecht, M. In Optoelectronic and Photonics Applications; Zysman-Colman, E., Ed.; John Wiley \& Sons Ltd, Chichester, 2017, vol. 1, pp 617-654. (b) Macchioni, A. The Middle-Earth between Homogeneous and Heterogeneous Catalysis in Water Oxidation with Iridium. Eur. J. Inorg. Chem. 2019, 7-17.

10 (a) Savini, A.; Belanzoni, P.; Bellachioma, G.; Zuccaccia, C.; Zuccaccia, D.; Macchioni, A. Activity and degradation pathways of pentamethyl-cyclopentadienyliridium catalysts for water oxidation. Green Chem. 2011, 13, 3360-3374. (b) Zuccaccia, C.; Bellachioma, G.; Bortolini, O.; Bucci, A.; Savini, A.; Macchioni, A. Transformation of a Cp*-Iridium(III) Precatalyst for Water Oxidation when Exposed to Oxidative Stress. Chem. Eur. J. 2014, 20, 3446-3456. (c) Savini, A.; Bucci, A.; Bellachioma, G.; Rocchigiani, L.; Zuccaccia, C.; Llobet, A.; Macchioni, A. Mechanistic Aspects of Water Oxidation Catalyzed by Organometallic Iridium Complexes. Eur. J. Inorg. Chem. 2014, 690-697. (d) Yang, K. R.; Matula, A. J.; Kwon, G.; Hong, J.; Sheehan, S. W.; Thomsen, J. M.; Brudvig, G. W.; Crabtree, R. H.; Tiede, D. M.; Chen, L. X.; Batista, V. S. Solution Structures of Highly Active Molecular Ir Water-Oxidation Catalysts from Density Functional Theory Combined with High-Energy X-ray Scattering and EXAFS Spectroscopy. J. Am. Chem. Soc. 2016, 138, 5511-5514.

11 (a) Woods, J. A.; Lalrempuia, R.; Petronilho, A.; McDaniel, N. D.; Müller-Bunz, H.; Albrecht, M.; Bernhard, S. Carbene iridium complexes for efficient water oxidation: scope and mechanistic insights. Energy Environ. Sci. 2014, 7, 2316-2328. (b) Corbucci, I.; Petronilho, A.; Muller-Bunz, H.; Rocchigiani, L.; Albrecht, M.; Macchioni, A. Substantial Improvement of Pyridine-Carbene Iridium Water Oxidation Catalysts by a Simple Methyl-to-Octyl Substitution. ACS Catal. 2015, 5, 2714-2718. (c) Corbucci, I.; Zaccaria, F.; Heath, R.; Gatto, G.; Zuccaccia, C.; Albrecht, M.; Macchioni, A. Iridium Water Oxidation Catalysts Based on Pyridine-Carbene Alkyl-Substituted Ligands. Chem CatChem 2019, 11, 5353-5361. 
${ }^{12}$ For examples of more active Ir-catalysts containing non-triazolylidene based ligands, see: (a) Codola, Z.; Cardoso, J. M. S.; Royo, B.; Costas, M.; Lloret-Fillol, J. Highly effective water oxidation catalysis with iridium complexes through the use of $\mathrm{NaIO}_{4}$. Chem. Eur. J. 2013, 19, 7203-13. (b) Menendez Rodriguez, G.; Bucci, A.; Hutchinson, R.; Bellachioma, G.; Zuccaccia, C.; Giovagnoli, S.; Idriss, H.; Macchioni, A. Extremely Active, Tunable, and pH-Responsive Iridium Water Oxidation Catalysts. ACS Energy Lett. 2017, 2, 105-110.

${ }^{13}$ Mazloomi, Z.; Pretorius, R.; Pàmies, O.; Albrecht, M.; Diéguez, M. Triazolylidene Iridium Complexes for Highly Efficient and Versatile Transfer Hydrogenation of $\mathrm{C}=\mathrm{O}$, $\mathrm{C}=\mathrm{N}$, and $\mathrm{C}=\mathrm{C}$ Bonds and for Acceptorless Alcohol Oxidation. Inorg. Chem. 2017, 56, $11282-11298$.

${ }^{14}$ Petronilho, A.; Llobet, A.; Albrecht, M. Ligand Exchange and Redox Processes in Iridium Triazolylidene Complexes Relevant to Catalytic Water Oxidation. Inorg. Chem. 2014, 53, 12896-12901.

15 (a) Parent, A. R.; Crabtree, R. H.; Brudig, G. W. Comparison of primary oxidants for water-oxidation catalysis. Chem. Soc. Rev. 2013, 42, 2247-2252. (b) Sackville, E. V.; Marken, F.; Hintermair, U. Electrochemical and Kinetic Insights into Molecular Water Oxidation Catalysts Derived from Cp* $\operatorname{Ir}$ (pyridine-alkoxide) Complexes. ChemCatChem 2018, 10, 4280-4291. (c) Olivares, M.; van der Ham, C. J. M.; Mdluli, V.; Schmidtendorf, M.; Müller-Bunz, H.; Verhoeven, T. W. G. M.; Li, M.; Niemantsverdriet, J. W.; Hetterscheid, D. G. H.; Bernhard, S.; Albrecht, M. Relevance of Chemical vs. Electrochemical Oxidation of Tunable Carbene Iridium Complexes for Catalytic Water Oxidation. Eur. J. Inorg. Chem. 2020, 801-812.

${ }^{16}$ Blakemore, J. D.; Schley, N. D.; Balcells, D.; Hull, J. F.; Olack, G. W.; Incarvito, C. D.; Eisenstein, O.; Brudvig, G. W.; Crabtree, R. H. Half-Sandwich Iridium Complexes for Homogeneous Water-Oxidation Catalysis. J. Am. Chem. Soc. 2010, 132, 1601716029.

${ }^{17}$ Hintermair, U.; Sheehan, S. W.; Parent, A. R.; Ess, D. H.; Richens, D. T.; Vaccaro, P. H.; Brudvig, G. W.; Crabtree, R. H. Precursor Transformation during Molecular Oxidation Catalysis with Organometallic Iridium Complexes. J. Am. Chem. Soc. 2013, $135,10837-10851$.

${ }^{18}$ Residual solvent has been excluded by using pure re-crystallized material which does not contain any residual solvent, see ref 13 for X-ray structures. Halide oxidation has been discarded as an option, as chloride oxidation would only consume 8 oxidizing 
equivalents if perchlorate were formed; moreover, using the chloride free aqua complex does not lower the equivalents of CAN used before CAN consumption is productive (see ref 11a). Considering the low solubility of $\mathrm{O}_{2}$ in $\mathrm{H}_{2} \mathrm{O}(1.25 \mathrm{mM})$, also saturation of the solution by $\mathrm{O}_{2}$ prior to detection by $\mathrm{MS}$ in the headspace has been eliminated as 1.25 TON (use of 5 eq CAN) would already lead to saturation at $1 \mathrm{mM}$ catalyst concentration. Moreover, Clark electrode measurements in solution would not be affected by this effect. Finally, interference with hardware seems highly unlikely when considering that different flasks have been used, yet the unproductive equivalents of CAN are constantly $25 \pm 5$ for all three complexes, suggesting a programmed rather than a coincidental quench of these equivalents.

${ }^{19}$ Bucci, A.; Menendez Rodriguez, G.; Bellachioma, G.; Zuccaccia, C.; Poater, A.; Cavallo, L.; Macchioni, A. An Alternative Reaction Pathway for Iridium-Catalyzed Water Oxidation Driven by Cerium Ammonium Nitrate (CAN). ACS Catal. 2016, 6, 4559 $-4563$.

${ }^{20}$ (a) Schley, N. D.; Blakemore, J. D.; Subbaiyan, N. K.; Incarvito, C. D.; D’Souza, F.; Crabtree, R. H.; Brudvig, G. W. Distinguishing Homogeneous from Heterogeneous Catalysis in Electrode-Driven Water Oxidation with Molecular Iridium Complexes. $J$. Am. Chem. Soc. 2011, 133, 10473-10481. (b) Blakemore, J. D.; Schley, N. D.; Olack, G. W.; Incarvito, C. D.; Brudvig, G. W.; Crabtree, R. H. Anodic deposition of a robust iridium-based water-oxidation catalyst from organometallic precursors. Chem. Sci. 2011, 2, 94-98.

${ }^{21}$ Parent, A. R.; Brewster, T. P.; Wolf, W. D.; Crabtree, R. H.; Brudvig, G. W. Sodium Periodate as a Primary Oxidant for Water-Oxidation Catalysts. Inorg. Chem. 2012, 51, $6147-6152$.

22 This contrast from what has been recently reported for some well-known Ir-water oxidation catalysts that show deposition of catalytic material onto the electrode at $\mathrm{pH} 5.6$ and not at pH 1. See: van Dijk, B.; Rodriguez, G. M.; Wu, L.; Hofmann, J. P.; Macchioni, A.; Hetterscheid, D. G. H. The Influence of the Ligand in the Iridium Mediated Electrocatalyic Water Oxidation. ACS Catal. 2020, 10, 4398-4410.

${ }^{23}$ We also studied the deep blue solution observed during the $\mathrm{NaIO}_{4}$-mediated water oxidation with the thiazole-trz iridium complex 2 , which featured an absorption band at $\lambda_{\max } \sim 590 \mathrm{~nm}$ (Figure S38). These UV-vis properties are reminiscent to those of Crabtree's dimeric iridium species $\left[(\mathrm{C}, \mathrm{N}) \mathrm{X}_{2} \operatorname{Ir}\left(\mu_{2}-\mathrm{X}\right)_{2} \operatorname{Ir} \mathrm{X}_{2}(\mathrm{C}, \mathrm{N})\right](\mathrm{X}=\mathrm{O}, \mathrm{OH}),{ }^{6 e, 21}$ which has recently been proposed as the active species during water oxidation catalysis with 
$[\mathrm{Cp} * \operatorname{Ir}($ pyalk $) \mathrm{X}]\left(\mathrm{X}=\mathrm{Cl}, \mathrm{OH}\right.$, pyalk $=2-\left(2^{\prime}\right.$-pyridyl $)-2$-propanoate $){ }^{6 \mathrm{j}, 10 \mathrm{~d}, 17}$ See also Thomsen, J. M.; Sheehan, S. W.; Hashmi, S. M.; Campos, J.; Hintermair, U.; Crabtree, R. H.; Brudvig, G. W. Electrochemical Activation of Cp* Iridium Complexes for Electrode-Driven Water-Oxidation Catalysis. J. Am. Chem. Soc. 2014, 136, 1382613834.

${ }^{24}$ Four independent runs gave consistently very similar TOF $=4.4 \pm 0.2 \mathrm{~s}^{-1}$, see Figure S37.

${ }^{25}$ Remarkably, though, the higher $\mathrm{pH}$ had a detrimental effect on the TOF of complex 4 , which decreased from 4.24 to $1.78 \mathrm{~s}^{-1}$ (Table 1 ; entry 8 vs 12 ). This may point to a more complex mechanism. 


\section{For Table of Contents Only}

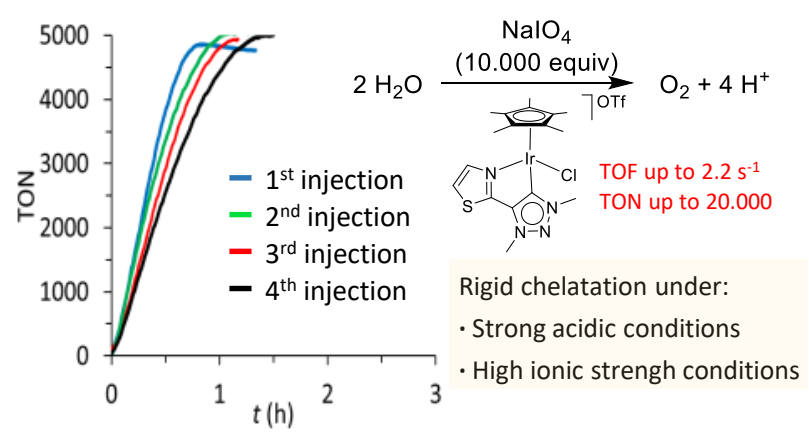

We investigated iridium complexes with differently stabilized triazole-derived carbene ligands for water oxidation catalysis. The effect of ligand chelation and sacrificial oxidant on the integrity of these triazole-based carbene iridium water oxidation catalysts has been studied. 